\title{
Deactivation Pathways of Neutral Ni(II) Polymerization Catalysts
}

\author{
Andreas Berkefeld and Stefan Mecking* \\ University of Konstanz, Chair of Chemical Materials Science, Department of Chemistry, \\ Universitätsstrasse 10, D-78457 Konstanz, Germany
}

E-mail: stefan.mecking@uni-konstanz.de

\begin{abstract}
The novel dimethyl sulfoxide (DMSO)-coordinated complex [(N,O)Ni(CH$)(\mathrm{DMSO})]$ 1-DMSO; $\left.(\mathrm{N}, \mathrm{O})=\kappa^{2}-\mathrm{N}, \mathrm{O}-\left(2,6-\left(3,5-\left(\mathrm{F}_{3} \mathrm{C}\right)_{2} \mathrm{C}_{6} \mathrm{H}_{3}\right)_{2} \mathrm{C}_{6} \mathrm{H}_{3}\right)-\mathrm{N}=\mathrm{CH}-\left(3,5-\mathrm{I}_{2}-2-\mathrm{OC}_{6} \mathrm{H}_{2}\right)\right\}$ was found to be a well-defined, very reactive precursor that enables direct observation of the activation and deactivation of neutral $\mathrm{Ni}(\mathrm{II})$ catalysts. Preparative reaction with ethylene afforded the ethyl complex [(N,O)Ni( $\left.\left.{ }^{\alpha} \mathrm{CH}_{2}{ }^{\beta} \mathrm{CH}_{3}\right)(\mathrm{DMSO})\right](2-\mathrm{DMSO})$. 2-DMSO is subject to interconversion of the ${ }^{\alpha} \mathrm{C}$ and ${ }^{\beta} \mathrm{C}$ moieties via an intermediate $[(\mathrm{N}, \mathrm{O}) \mathrm{Ni}(\mathrm{II}) \mathrm{H}$ (ethylene)] complex (this process is slow on the NMR time scale). Exposure of 1-DMSO to ethylene in DMSO solution at $55^{\circ} \mathrm{C}$ results in partial reaction to form propylene (pseudo-first-order rate constant $k_{\text {ins, }, \mathrm{Me}}=6.8 \pm 0.3 \times$ $10^{-4} \mathrm{~s}^{-1}$ at an ethylene concentration of $0.15 \mathrm{M}$ ) and conversion to 2-DMSO, which catalyzes the conversion of ethylene to butenes. A relevant decomposition route of the catalyst precusor is the bimolecular elimination of ethane $\left[\Delta H^{+}=(57 \pm 1) \mathrm{kJ} \mathrm{mol}^{-1}\right.$ and $\Delta S^{+}=-(129 \pm 2) \mathrm{J} \mathrm{mol}^{-1} \mathrm{~K}^{-1}$ over the temperature range $55-80$ ${ }^{\circ} \mathrm{C}$ ]. This reaction is specific to the $\mathrm{Ni}(\mathrm{II})-\mathrm{Me}$ complex; corresponding homocoupling of the higher $\mathrm{Ni}(\mathrm{II})$-alkyls of the propagating species in catalytic $\mathrm{C}-\mathrm{C}$ linkage of ethylene was not observed, but $\mathrm{Ni}(\mathrm{II})-\mathrm{Me}$ reacted with $\mathrm{Ni}(\mathrm{II})$ - Et to form propane, as concluded from studies with 2-DMSO and its analogue that is perdeuterated in the $\mathrm{Ni}(\mathrm{II})-\mathrm{Et}$ moiety. Under the reaction conditions of the aforementioned catalytic $\mathrm{C}-\mathrm{C}$ linkage of ethylene, additional ethane evolves from the reaction of intermediate $\mathrm{Ni}(\mathrm{II})-\mathrm{Et}$ with $\mathrm{Ni}(\mathrm{II})-\mathrm{H}$. This is independently supported by reaction of 2-DMSO with the separately prepared hydride complex $\left[(\mathrm{N}, \mathrm{O}) \mathrm{NiH}\left(\mathrm{PMe}_{3}\right)\right]\left(3-\mathrm{PMe}_{3}\right)$ to afford ethane. Kinetic studies show this reaction to be bimolecular $\left[\Delta H^{+}=\right.$ $(47 \pm 6) \mathrm{kJ} \mathrm{mol}^{-1}$ and $\Delta S^{+}=-(117 \pm 15) \mathrm{J} \mathrm{mol}^{-1} \mathrm{~K}^{-1}$ over the temperature range $6-35^{\circ} \mathrm{C}$. In contrast to these reactions identified as decomposition routes, hydrolysis of $\mathrm{Ni}(\mathrm{II})$-alkyls by added water $\left(\mathrm{D}_{2} \mathrm{O}\right.$; $\mathrm{H}_{2} \mathrm{O}$ ) occurred only to a minor extent for the $\mathrm{Ni}(\mathrm{II})$ - Me catalyst precursor, and no clear evidence of hydrolysis was observed for higher $\mathrm{Ni}(\mathrm{II})$-alkyls. The rate of the aforementioned insertion of ethylene in 1-DMSO and the rate of catalytic ethylene dimerization are not affected by the presence of water, indicating that water also does not compete significantly with the substrate for binding sites.
\end{abstract}

\section{Introduction}

Olefin polymerization by cationic complexes of $\mathrm{d}^{8}$ metals (late transition metals) has been studied intensely in the past decade. ${ }^{1}$ These catalysts are much more tolerant toward polar reagents in general than are their highly oxophilic early transition metal counterparts.

Not only are cationic Ni(II) and Pd(II) diimine complexes precursors to versatile polymerization catalysts, but the $\mathrm{Pd}$ (II) complexes are also exceptionally well-suited for mechanistic studies. From ether adducts $\left[(\text { diimine }) \mathrm{PdMe}\left(\mathrm{OEt}_{2}\right)\right]^{+}$, the ether is easily displaced by olefin. Olefin complexes and their reactivities can be observed in low-temperature NMR experiments, providing mechanistic insights of general scope..$^{2-7}$

(1) (a) Ittel, S. D.; Johnson, L. K.; Brookhart, M. Chem. Rev. 2000, 100 1169-1203. (b) Gibson, V. C.; Spitzmesser, S. K. Chem. Rev. 2003, 103, 283-315. (c) Mecking, S. Coord. Chem. Rev. 2000, 203, 325351. (d) Mecking, S. Angew. Chem., Int. Ed. 2001, 40, 534-540. (e) Guan, Z. Chem.-Eur. J. 2002, 8, 3086-3092. (f) Domski, G. J.; Rose, J. M.; Coates, G. W.; Bolig, A. D.; Brookhart, M. Prog. Polym. Sci. 2007, 32, 30-92. (g) Berkefeld, A.; Mecking, S. Angew. Chem., Int Ed. 2008, 47, 2538-2542.
These studies have promoted a renewed interest in neutral Ni(II) polymerization catalysts. ${ }^{8-11}$ Neutral Ni(II) complexes have been applied industrially for a long time for linear ethylene oligomerization in a biphasic butanediole/hydrocarbon system. ${ }^{12}$ While this is desirable in view of their unique synthetic utility, such as controllable degrees of polymer branching and thus crystallinity, high polymerization rates, and tolerance toward polar environments, neutral Ni(II) complexes are much less

(2) Johnson, L. K.; Killian, C. M.; Brookhart, M. J. Am. Chem. Soc. 1995, $117,6414-6115$.

(3) (a) Johnson, L. K.; Mecking, S.; Brookhart, M. J. Am. Chem. Soc. 1996, 118, 267-268. (b) Mecking, S.; Johnson, L. K.; Wang, L.; Brookhart, M. J. Am. Chem. Soc. 1998, 120, 888-899.

(4) (a) Foley, S. R.; Stockland, R. A., Jr.; Shen, H.; Jordan, R. F. J. Am. Chem. Soc. 2003, 125, 4350-4361. (b) Foley, S. R.; Shen, H.; Qadeer, U. A.; Jordan, R. F. Organometallics 2004, 23, 600-609. (c) Williams, B. S.; Leatherman, M. D.; White, P. S.; Brookhart, M. J. Am. Chem. Soc. 2005, 127, 5132-5146. (d) Wu, F.; Foley, S. R.; Burns, C. T.; Jordan, R. F. J. Am. Chem. Soc. 2005, 127, 1841-1853. (e) Groux, L. F.; Weiss, T.; Reddy, D. N.; Chase, P. A.; Piers, W. E.; Ziegler, T; Parvez, M.; Benet-Buchholz, J. J. Am. Chem. Soc. 2005, 127, 1854 1869. (f) Li, W.; Zhang, X.; Meetsma, A.; Hessen, B. J. Am. Chem. Soc. 2004, 126, 12246-12247. (g) Luo, S.; Jordan, R. F. J. Am. Chem. Soc. 2006, 128, 12072-12073. (h) Chen, C.; Luo, S.; Jordan, R. F. J. Am. Chem. Soc. 2008, 130, 12892-12893. 
amenable to mechanistic studies than are the aforementioned cationic Pd(II) complexes and have been less investigated. Jenkins and Brookhart ${ }^{13}$ reported an elegant in-depth NMR spectroscopic study of an anilinotropone system, which in particular addressed species responsible for chain growth and their dynamics. In regard to catalyst deactivation, heating of the hydride complex $\left[(\mathrm{N}, \mathrm{O}) \mathrm{Ni}\left(\mathrm{PPh}_{3}\right) \mathrm{H}\right]$, which was observed in separate experiments as an intermediate in catalysis, afforded the bischelate complex $\left[(\mathrm{N}, \mathrm{O})_{2} \mathrm{Ni}\right]$ as one ultimate product. Irreversible acid-base reaction of the free ligand $[\mathrm{N}, \mathrm{O}] \mathrm{H}$

(5) Berkefeld, A.; Mecking, S. Angew. Chem., Int. Ed. 2006, 45, 60446046.

(6) (a) Tempel, D. J.; Johnson, L. K.; Huff, R. L.; White, P. S ; Brookhart, M. J. Am. Chem. Soc. 2000, I22, 6686-6700. (b) Leatherman, M. D.; Svejda, S. A.; Johnson, L. K.; Brookhart, M. J. Am. Chem. Soc. 2003, 125, 3068-3081.

(7) (a) Deng, L.; Margl, P. M.; Ziegler, T. J. Am. Chem. Soc. 1997, 119, 1094-1100. (b) Deng, L.; Woo, T. K.; Cavallo, L.; Margl, P. M.; Ziegler, T. J. Am. Chem. Soc. 1997, 119, 6177-6186. (c) Michalak, A.; Ziegler, T. Organometallics 2000, 19, 1850-1858. (d) von Schenck, H.; Strömberg, S.; Zetterberg, K.; Ludwig, M.; Åkermark, B.; Svensson, M. Organometallics 2001, 20, 2813-2819.

(8) (a) Braunstein, P.; Pietsch, J.; Chauvin, Y.; Mercier, S.; Saussine, L.; DeCian, A.; Fischer, J. J. Chem. Soc., Dalton Trans. 1996, 35713574. (b) Braunstein, P.; Pietsch, J.; Chauvin, Y.; DeCian, A.; Fischer, J. J. Organomet. Chem. 1997, 529, 387-393. (c) Wang, C.; Friedrich, S.; Younkin, T. R.; Li, R. T.; Grubbs, R. H.; Bansleben, D. A.; Day, M. W. Organometallics 1998, 17, 3149-3151. (d) Johnson, L. K.; Bennett, A. M. A.; Ittel, S. D.; Wang, L.; Parthasarathy, A.; Hauptman, E.; Simpson, R. D.; Feldman, J.; Coughlin, E. B. (DuPont). WO98/ 30609, 1998. (e) Pietsch, J.; Braunstein, P.; Chauvin, Y. New J. Chem. 1998, 22, 467-472. (f) Younkin, T. R.; Connor, E. F.; Henderson, J. I.; Friedrich, S. K.; Grubbs, R. H.; Bansleben, D. A. Science $\mathbf{2 0 0 0}$ 287, 460-462. (g) Rachita, M. J.; Huff, R. L.; Bennett, J. L.; Brookhart, M. J. Polym. Sci. 2000, 38, 4627-4640. (h) Hicks, F. A.; Brookhart, M. Organometallics 2001, 20,3217-3219. (i) Soula, R.; Broyer, J. P.; Llauro, M. F.; Tomov, A.; Spitz, R.; Claverie, J.; Drujon, X.; Malinge, J.; Saudemont, T. Macromolecules 2001, 34, 2438-2442. (j) Gibson, V. C.; Tomov, A.; White, A. J. P.; Williams, D. J. Chem. Commun. 2001, 719-720. (k) Hicks, F. A.; Jenkins, J.; Brookhart, M. Organometallics 2003, 22, 3533-3545. (1) Zuideveld, M. A.; Wehrmann, P.; Röhr, C.; Mecking, S. Angew. Chem., Int. Ed. 2004, 43, 869-873. (m) Speiser, F.; Braunstein, P.; Saussine, L. Acc. Chem. Res. 2005, 38, 784-793. (n) Zhang, L.; Brookhart, M.; White, P. S. Organometallics 2006, 25, 1868-1874. (o) Kuhn, P.; Sémeril, D.; Jeunesse, C.; Matt, D.; Neuburger, M.; Mota, A. Chem.-Eur. J. 2006, 12, 52105219. (p) Göttker-Schnetmann, I.; Wehrmann, P.; Röhr, C.; Mecking, S. Organometallics 2007, 26, 2348-2362. (q) Yu, S.-M.; Berkefeld, A.; Göttker-Schnetmann, I.; Müller, G.; Mecking, S. Macromolecules 2007, 40, 421-428. (r) Bastero, A.; Göttker-Schnetmann, I.; Röhr, C. Mecking, S. Adv. Synth. Catal. 2007, 349, 2307-2316. (s) Guironnet, D.; Rünzi, T.; Göttker-Schnetmann, I.; Mecking, S. Chem. Commun. 2008, 4965-4967. (t) Wehrmann, P.; Mecking, S. Organometallics 2008, 27, 1399-1408. (u) Lavanant, L.; Rodriguez, A.-S.; Carpentier, J.-F.; Jordan, R. F. Organometallics 2008, 27, 2107-2117. (v) Rodriguez, B. A.; Delferro, M.; Marks, T. J. Organometallics 2008, 27, 2166-2168. (w) Zhou, X.; Bontemps, S.; Jordan, R. S. Organometallics 2008, 27, 4821-4824.

(9) Early related work: (a) Reference 12a. (b) Ostoja Starzewski, K. A.; Witte, J. Angew. Chem., Int. Ed. Engl. 1985, 24, 599-601. (c) Klabunde, U.; Ittel, S. D. J. Mol. Catal. 1987, 41, 123-134.

(10) (a) Bauers, F. M.; Mecking, S. Angew. Chem., Int. Ed. 2001, 40, 30203022. (b) Soula, R.; Novat, C.; Tomov, A.; Spitz, R.; Claverie, J.; Drujon, X.; Malinge, J.; Saudemont, T. Macromolecules 2001, 34, 2022-2026. (c) Göttker-Schnetmann, I.; Korthals, B.; Mecking, S. J. Am. Chem. Soc. 2006, 128, 7708-7709. (d) Mecking, S. Colloid Polym. Sci. 2007, 285, 605-619.

(11) (a) Chan, M. S. W.; Deng, L.; Ziegler, T. Organometallics 2000,19 , 2741-2750. (b) Zeller, A.; Strassner, T. J. Organomet. Chem. 2006, $691,4379-4385$.

(12) (a) Keim, W.; Kowaldt, F. H.; Goddard, R.; Kriiger, C. Angew. Chem., Int. Ed. Engl. 1978, 17, 466-467. (b) Keim, W. Chem. Ing. Tech. 1984, 56, 850-853. (c) Vogt, D. In Aqueous-Phase Organometallic Chemistry; Cornils, B., Herrmann, W. A., Eds.; Wiley-VCH: Weinheim, Germany, 1998; pp 541-547.

(13) Jenkins, J. C.; Brookhart, M. J. Am. Chem. Soc. 2004, 126, 58275842 . (assumed to be liberated via reductive elimination from the intermediate nickel hydride species under polymerization conditions) with the propagating metal species was suggested to be a decomposition pathway.

We now report the first comprehensive study of deactivation of neutral Ni(II) polymerization catalysts, based on direct NMR spectroscopic observations during catalytic chain growth and quantitative kinetic studies of relevant intermediates. In this context, the reactivity toward the most ubiquitous polar reagent, water, is also adressed.

\section{Results and Discussion}

Synthesis and General Reactivity of DMSO Complex 1-DMSO. The overall catalytic activity of complexes [(N,O)$\mathrm{NiMe}(\mathrm{L})$ ] for olefin polymerization depends substantially on the coordination strength of the ligand L. Dissociation of $\mathrm{L}$ appears to be a limiting step for polymerization, and the reactivity in general, of such complexes. Unfortunately, the introduction of weakly coordinating ligands $\mathrm{L}$ is challenging in terms of synthetic strategies. The use of [(tmeda) $\left.\mathrm{NiMe}_{2}\right]$ as a convenient $\mathrm{Ni}(\mathrm{II})$ - methyl source for the synthesis of complexes $[(\mathrm{N}, \mathrm{O}) \mathrm{NiMe}(\mathrm{L})]$ intrinsically introduces the weakly coordinating bidendate ligand $N, N, N^{\prime}, N^{\prime}$-tetramethylethylenediamine (tmeda). Tmeda-coordinated neutral Ni(II)-methyl precursors proved to be highly active in ethylene polymerization. However, several interconverting $\mathrm{Ni}(\mathrm{II})$-methyl species can be distinguished by NMR spectroscopy in solutions of $[(\mathrm{N}, \mathrm{O})$ $\mathrm{NiMe}(\mathrm{tmeda})]$ in either coordinating or noncoordinating solvents. ${ }^{14}$ Therefore, we focused on the development of a catalyst precursor that is highly active for ethylene polymerization but promotes chain growth from a single defined $\mathrm{Ni}(\mathrm{II})$ - methyl species in solution. Dimethyl sulfoxide (DMSO) was attractive as a solvent for our studies because of its unlimited miscibility with water. Also, NMR spectroscopic studies suggest a relatively weak binding of DMSO to Ni(II)-alkyls. ${ }^{15}$ The neutral $\mathrm{Ni}(\mathrm{II})$-methyl DMSO complex [(N,O) NiMe(DMSO) $\{\mathbf{1 -}$ DMSO; $(\mathrm{N}, \mathrm{O})=\kappa^{2}-\mathrm{N}, \mathrm{O}-\left(2,6-\left(3,5-\left(\mathrm{F}_{3} \mathrm{C}_{2} \mathrm{C}_{6} \mathrm{H}_{3}\right)_{2} \mathrm{C}_{6} \mathrm{H}_{3}\right)-\mathrm{N}=\mathrm{CH}-(3,5-\right.$ $\left.\left.\mathrm{I}_{2}-2-\mathrm{OC}_{6} \mathrm{H}_{2}\right)\right\}$ is formed from the reaction of [(tmeda) $\left.\mathrm{NiMe}_{2}\right]$ with the free salicylaldimine $[\mathrm{N}, \mathrm{O}] \mathrm{H}$ in DMSO solution at room temperature (eq 1 ). Tmeda was efficiently removed by repetitive cycles of evaporation of solvent under high vacuum at $30^{\circ} \mathrm{C}$ and redissolution of the residual red solid in fresh DMSO. Even after thorough treatment under high vacuum, the DMSO adduct of the desired DMSO complex, [(N,O) NiMe(DMSO)] DMSO, was obtained. This product contained minor amounts of the

(14) The 2D NMR analysis of complex [(N,O)NiMe(tmeda)] in DMSO$d_{6}$ showed that tmeda can bind to the nickel center in a chelating $\kappa^{2}-$ fashion, with the salicylaldiminato ligand coordinated solely via its phenoxy oxygen atom in a $\kappa^{1}$-fashion. Complexes involving $\kappa^{1}$-tmeda also occur, but their formation is less favored. In DMSO- $d_{6}$ solution, the $\kappa^{2}$-tmeda complex forms an equilibrium with the corresponding solvent complex and free tmeda. Key ${ }^{1} \mathrm{H}\left({ }^{13} \mathrm{C}\right)$ NMR resonances of the $\kappa^{2}$-tmeda complex: $-1.79(-15.0)$ (Ni(II) $\left.-\mathrm{CH}_{3}\right), 1.64(45.9), 1.82$ (47.5), $2.01(48.6), 2.35$ (45.9) $\left(4 \times \mathrm{N}-\mathrm{CH}_{3}\right.$, tmeda $), 11.09(160.9)$ $(-\mathrm{CH}=\mathrm{N}-) \mathrm{ppm}$.

(15) Rapid ethylene consumption was observed in toluene- $d_{8}$ and $\mathrm{CD}_{2} \mathrm{Cl}_{2}$ solutions of 1-DMSO at ambient temperatures. No defined resonances of higher $(\mathrm{R}>\mathrm{Me}) \mathrm{Ni}(\mathrm{II})$-alkyls could be detected besides the gradual ingrowth of a broad polymer or polymeryl resonance at $2.03 \mathrm{ppm}$. Although the rate of ethylene consumption could be lowered by decreasing the reaction temperature, no defined higher $\mathrm{Ni}$ (II) - alkyl species were observed at temperatures down to $0^{\circ} \mathrm{C}$ either. Because of their poor miscibility with water, in particular at lower temperatures, toluene and methylene chloride are not suitable for studying the influence of water on the polymerization-active $\mathrm{Ni}$ (II)-alkyl species under chain-growth conditions. 


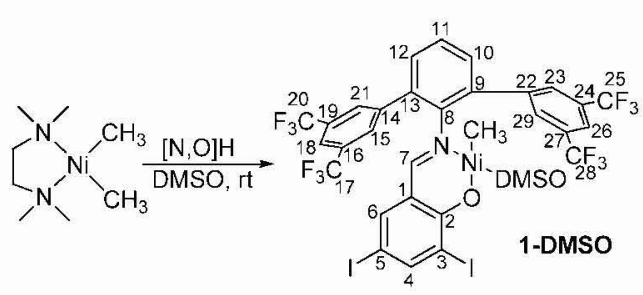

bisligand complex $\left[(\mathrm{N}, \mathrm{O})_{2} \mathrm{Ni}\right]$. Extraction of the crude product with methanol at $-78{ }^{\circ} \mathrm{C}$ and rapid collection onto a filter frit afforded 1-DMSO free of additional solvent in 56\% yield.

A single $\mathrm{Ni}(\mathrm{II})-$ methyl species is observed, which resonates at $-1.19\left({ }^{1} \mathrm{H}\right)$ and $-8.1\left({ }^{13} \mathrm{C}\right) \mathrm{ppm}$ in DMSO- $d_{6}$ solution. Free DMSO- $h_{6}$ is observed at $2.54\left({ }^{1} \mathrm{H}\right)$ and $40.4\left({ }^{13} \mathrm{C}\right)$ ppm as a result of exchange with the (deuterated) solvent. Twodimensional (2D) NMR spectroscopic analysis suggests that the cis isomer forms exclusively in DMSO solution, with the Ni(II)methyl group trans to the phenoxy oxygen atom of the salicylaldiminato ligand. Dipolar couplings between the $\mathrm{Ni}(\mathrm{II})-\mathrm{CH}_{3}$ protons and the ortho and para protons of the 3,5$\left(\mathrm{F}_{3} \mathrm{C}_{2} \mathrm{C}_{6} \mathrm{H}_{3}\right.$ moieties of the terphenylaniline unit are observed by $2 \mathrm{D}$ rotating-frame nuclear Overhauser effect NMR spectroscopy (ROESY) at $25{ }^{\circ} \mathrm{C}$. The ${ }^{1} \mathrm{H}$ and ${ }^{13} \mathrm{C}$ NMR chemical shifts of the imine moiety $(-H C=\mathrm{N}-$ ) strongly depend on the nature of the neutral monodentate ligand coordinated to the metal center and are observed at $8.13\left({ }^{1} \mathrm{H}\right)$ and $169.3\left({ }^{13} \mathrm{C}\right) \mathrm{ppm}$ in 1-DMSO. Complete NMR spectroscopic characterization of 1-DMSO is provided in the Experimental Section.

Both isomers are observed in $\mathrm{CD}_{2} \mathrm{Cl}_{2}$ solution, the trans isomer being the major species. $\mathrm{Ni}(\mathrm{II})-\mathrm{CH}_{3}$ resonances are observed at -1.15 and $-0.82 \mathrm{ppm}$ for the cis and trans isomers, respectively, and the corresponding resonances of coordinated DMSO are observed at 2.45 and $2.92 \mathrm{ppm}$. These spectral assignments of the $\mathrm{Ni}(\mathrm{II})-\mathrm{CH}_{3}$ resonances to the cis and trans isomers are in agreement with NMR chemical shifts observed for similar compounds. ${ }^{16}$ Exchange between coordinated and free DMSO occurs slowly on the NMR chemical-shift time scale (free DMSO is observed at $2.55 \mathrm{ppm}$ ). ${ }^{17}$

$\mathrm{Ni}(\mathrm{II})-$ methyl complexes of the type $[(\mathrm{N}, \mathrm{O}) \mathrm{NiMe}(\mathrm{L})]$ are suitable precursors to highly active catalysts for the bulk polymerization of ethylene. Polymerizations with 1-DMSO were carried out at catalyst loadings of $1 \mu \mathrm{mol}$ in $80 \mathrm{~mL}$ of toluene at $20^{\circ} \mathrm{C}$ for $1 \mathrm{~h}$ at varying ethylene pressures. Overall turnover frequencies [TOFs, measured in units of $\mathrm{TO} \mathrm{h}^{-1}$, where TO stands for $\left(\mathrm{mol} \text { of } \mathrm{C}_{2} \mathrm{H}_{4} \text { ) ( } \mathrm{mol} \text { of } \mathbf{1}\right)^{-1}$ ] were nearly independent of the ethylene concentration in the pressure range from 10 bar $\left(3.9 \times 10^{4} \mathrm{TO} \mathrm{h}^{-1}\right)$ to $30 \mathrm{bar}\left(4.5 \times 10^{4} \mathrm{TO} \mathrm{h}^{-1}\right)$. A highly linear semicrystalline polyethylene was obtained, with, for example, a molecular weight of $M_{\mathrm{n}}=1.4 \times 10^{5} \mathrm{~g} \mathrm{~mol}^{-1}\left(M_{\mathrm{w}} /\right.$ $M_{\mathrm{n}}=2.1,50 \%$ crystallinity; prepared at 30 bar). In polymer-

(16) Connor, E. F.; Younkin, T. R.; Henderson, J. I.; Waltman, A. W.; Grubbs, R. H. Chem. Commun. 2003, 2272-2273.

(17) Notably, rates of exchange of free and coordinated DMSO depend on the concentration of free DMSO, suggesting an associative mechanism. Second-order rate constants and activation parameters were determined for both isomers by variable-temperature ${ }^{1} \mathrm{H}$ NMR: $k_{\text {exch,DMSO,cis }}=1.0$ $\times 10^{4} \mathrm{M}^{-1} \mathrm{~s}^{-1}$ and $k_{\text {exch,DMSO,trans }}=1.1 \times 10^{4} \mathrm{M}^{-1} \mathrm{~s}^{-1}$ at $25^{\circ} \mathrm{C}$ (as determined by linear regression of Eyring plots; see the Supporting Information). A van't Hoff analysis of the equilibrium constant between the cis and trans isomers (as determined by variabletemperature ${ }^{1} \mathrm{H}$ NMR spectroscopy) over the temperature range from60 to $45^{\circ} \mathrm{C}$ yielded $\Delta H=(7.98 \pm 0.09) \mathrm{kJ} \mathrm{mol}^{-1}$ and $\Delta S=(21 \pm 1)$ $\mathrm{J} \mathrm{mol}^{-1} \mathrm{~K}^{-1}$ (see the Supporting Information). The difference in the free energies of the two isomers was determined to be $\Delta G=(1.71 \pm$ $0.31) \mathrm{kJ} \mathrm{mol}^{-1}$ at room temperature.

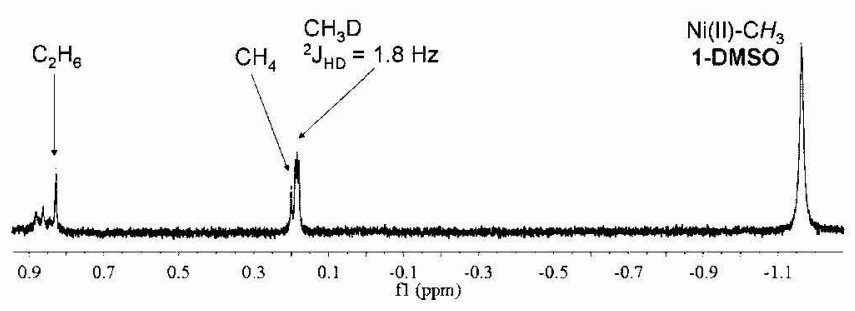

Figure 1. Formation of ethane (0.83 ppm) and $\mathrm{CH}_{3} \mathrm{D}\left(\mathrm{CH}_{4}\right)[0.19(0.20)$ ppm] from 1-DMSO ( $\mathrm{Ni}(\mathrm{II})-\mathrm{CH}_{3}$ at $-1.16 \mathrm{ppm}$ ) in the presence of 15 equiv of $\mathrm{D}_{2} \mathrm{O}$ at $70^{\circ} \mathrm{C}$ in DMSO- $d_{6}$.

ization experiments of variable duration $(5,20,30$, and $60 \mathrm{~min}$ ), the polymer yield increased linearly with time. This indicates a high stability of the active species under these conditions. ${ }^{18}$

Protolysis Reactions. Theoretical studies suggest that protolysis of the metal-carbon bond of neutral $\mathrm{Ni}$ (II)-alkyl complexes occurs from intermediately formed water complexes $\left[(\mathrm{N}, \mathrm{O}) \mathrm{NiR}\left(\mathrm{OH}_{2}\right)\right](\mathrm{R}=$ alkyl $){ }^{19}$ Attempts were undertaken to generate $\mathrm{Ni}(\mathrm{II})$-methyl water species from 1-DMSO in neat DMSO- $d_{6}$ solution. However, identical ${ }^{1} \mathrm{H}$ NMR spectra were observed when increasing amounts (up to 500 equiv) of water were added to DMSO- $d_{6}$ or methanol- $d_{4}{ }^{20}$ solutions of 1-DMSO, suggesting a weaker binding ability of water to the neutral $\mathrm{Ni}(\mathrm{II})$-alkyls. Immediate precipitation of 1-DMSO occurred in the presence of larger amounts $(>0.1 \mathrm{~mL})$ of water.

However, gradual formation of $\mathrm{CH}_{3} \mathrm{D}$ was observed upon warming of an aqueous ( 15 equiv of $\mathrm{D}_{2} \mathrm{O}$ ) DMSO- $d_{6}$ solution of 1-DMSO to $70{ }^{\circ} \mathrm{C}\left(\delta 0.18,1: 1: 1\right.$ triplet, ${ }^{2} J_{\mathrm{H}-\mathrm{D}}=1.8 \mathrm{~Hz}$; Figure 1$)$. The reaction proceeded very slowly $\left(\tau_{1 / 2} \approx 140 \mathrm{~min}\right.$ ), but no indicative ${ }^{1} \mathrm{H}$ NMR resonances that would account for the formation of a water complex $\left[(\mathrm{N}, \mathrm{O}) \mathrm{NiMe}\left(\mathrm{OH}_{2}\right)\right]$ were observed. A rate constant could not be extracted because a significant contribution to the overall decrease of the $\mathrm{Ni}(\mathrm{II})-\mathrm{CH}_{3}$ resonance of 1-DMSO arose from a second, more rapid waterindependent decomposition reaction (see below) that caused the gradual formation of $\mathrm{C}_{2} \mathrm{H}_{6}(\delta 0.83$; Figure 1$)$.

(18) Surprisingly, the apparent overall activities increased upon the addition of small excesses of DMSO to the catalyst toluene solution. The TOFs were observed to increase from $4.5 \times 10^{4} \mathrm{TO} \mathrm{h}^{-1}$ in the absence of an excess to $8.0 \times 10^{4}$ and $1.4 \times 10^{5} \mathrm{TO} \mathrm{h}^{-1}$ in the presence of 11 and 40 equiv of excess DMSO per Ni(II)-methyl, respectively, under 30 bar of ethylene pressure. The polymer molecular weights also increased: $M_{\mathrm{n}}$ of the polyethylenes obtained were in the range (3.03.6) $\times 10^{5} \mathrm{~g} \mathrm{~mol}^{-1}\left(M_{\mathrm{w}} / M_{\mathrm{n}}=2.5-2.7,50 \%\right.$ crystallinity $)$ in the presence of 40 equiv of excess DMSO as opposed to $1.4 \times 10^{5} \mathrm{~g}$ $\mathrm{mol}^{-1}$ in the absence of excess DMSO. Overall polymerization activities were constant with time. The presence of larger amounts of DMSO ( $\geq 100$ equiv) resulted in polymer precipitation at early reaction times, concomitant with a strong uncontrolled exotherm.

(19) Hristov, I. H.; DeKock, R. L.; Anderson, G. D. W.; GöttkerSchnetmann, I.; Mecking, S.; Ziegler, T. Inorg. Chem. 2005, 44, 78067818 .

(20) 1-DMSO readily dissolves in methanol- $d_{4} \cdot{ }^{1} \mathrm{H}$ and ${ }^{13} \mathrm{C}$ NMR spectra reveal single defined $\mathrm{Ni}(\mathrm{II})-\mathrm{CH}_{3}$ resonances at -1.28 and $-14.0 \mathrm{ppm}$, respectively, and signals for DMSO- $h_{6}$ at 2.67 and $40.4 \mathrm{ppm}$, respectively (complete ${ }^{1} \mathrm{H}$ and ${ }^{13} \mathrm{C}$ assignments are provided in the Supporting Information). However, the resonances could not be assigned unambiguously to a DMSO- or methanol-coordinated Ni(II)methyl species. Rapid ligand exchange between methanol and DMSO complexes, which presumably exist in equilibrium with each other, may result in an averaged $\mathrm{Ni}(\mathrm{II})-\mathrm{CH}_{3} \mathrm{NMR}$ signal. 2D ROESY spectra revealed no dipolar couplings between $\mathrm{Ni}(\mathrm{II})-\mathrm{CH}_{3}$ and DMSO protons; a rapid ligand exchange may prevent sufficient magnetization transfer. However, gradual formation of $\mathrm{CH}_{3} \mathrm{D}$ was observed at $40^{\circ} \mathrm{C}$, and a first-order rate constant was determined as $k_{\mathrm{obs}, \mathrm{CD}_{3} \mathrm{OD}}(313 \mathrm{~K})=$ $(4.2 \pm 0.1) \times 10^{-4} \mathrm{~s}^{-1}$ by monitoring the disapperance of the $\mathrm{Ni}(\mathrm{II})-$ $\mathrm{CH}_{3}$ resonance with time (see the Supporting Information). 


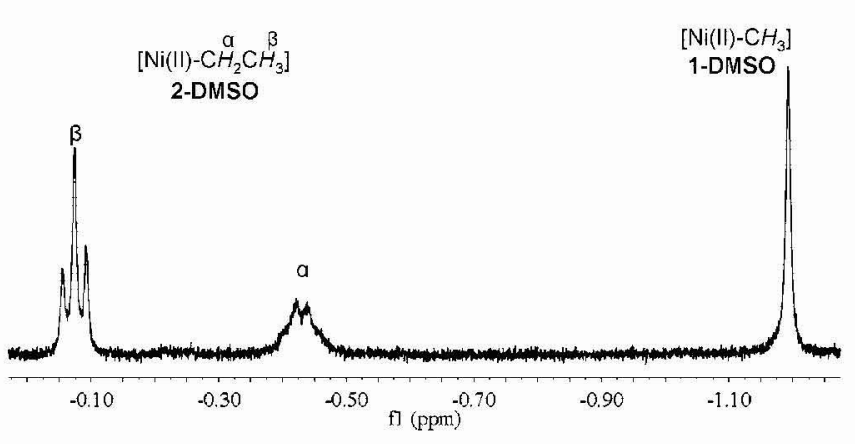

Figure 2. Ni(II)-alkyl region of the room temperature ${ }^{1} \mathrm{H}$ NMR spectrum of a 1:1 2-DMSO/1-DMSO mixture in DMSO- $d_{6}$ prepared in situ at $55^{\circ} \mathrm{C}$ in the NMR tube.

Direct Observation of Catalytic Chain Growth by NMR Spectroscopy. Exposure of 1-DMSO in DMSO- $d_{6}$ solution to excess ethylene at elevated temperature in an NMR tube resulted in the dimerization of ethylene to butenes. The overall rate of ethylene insertion into the $\mathrm{Ni}(\mathrm{II})$ - methyl bond of 1-DMSO was determined by monitoring the decrease of the $\mathrm{Ni}(\mathrm{II})-\mathrm{CH}_{3}$ resonance at $-1.19 \mathrm{ppm}$ as a function of time at $T=55^{\circ} \mathrm{C}$. For the pseudo-first-order rate constant of ethylene insertion,

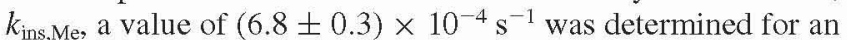
initial ethylene concentration of $\sim 150 \mathrm{mM}$. Unfortunately, the solubility of ethylene in DMSO is limited under the conditons studied. Initial ethylene concentrations varied between 3 and 6 equiv of $\mathrm{C}_{2} \mathrm{H}_{4}$ per $\mathrm{Ni}(\mathrm{II})-\mathrm{CH}_{3}$ at $55^{\circ} \mathrm{C}$. No accurate rates could be determined for higher initial ethylene concentrations to determine the order with respect to ethylene.

To our surprise, the neutral $\mathrm{Ni}(\mathrm{II})$-ethyl complex [(N,O)$\left.\mathrm{Ni}\left(\mathrm{C}_{2} \mathrm{H}_{5}\right)(\mathrm{DMSO})\right]$ (2-DMSO) was formed exclusively from the reaction of 1-DMSO and ethylene. Key ${ }^{1} \mathrm{H}$ NMR resonances of the $\alpha$-methylene and $\beta$-methyl protons of the $\mathrm{Ni}$ (II)-ethyl fragment were observed at $-0.42 \mathrm{ppm}$ (a severely broadened resonance) and $-0.07 \mathrm{ppm}$ (a broad triplet) at $55^{\circ} \mathrm{C}$. The broad resonance of the $\alpha$-methylene protons yielded a broadened quartet upon cooling to room temperature (Figure 2). The chemical shifts of both resonances remained almost unchanged upon temperature variation (see the next section for a discussion of the dynamics of 2-DMSO).

The formation of the neutral $\mathrm{Ni}(\mathrm{II})$ - propyl and $\mathrm{Ni}(\mathrm{II})$ - butyl species $[(\mathrm{N}, \mathrm{O}) \mathrm{Ni}(\mathrm{R})(\mathrm{S})]\left(\mathrm{R}=\mathrm{C}_{3} \mathrm{H}_{7}, \mathrm{C}_{4} \mathrm{H}_{9}\right.$, respectively; $\mathrm{S}=$ $\mathrm{C}_{2} \mathrm{H}_{4}, \mathrm{DMSO}$ ) was concluded from the evolution of propene and butenes monitored by ${ }^{1} \mathrm{H}$ NMR spectroscopy. Ethylene is dimerized into $85 \%$ 2-butene ( $36 \%$ cis vs $64 \%$ trans) and $\sim 15 \%$ 1-butene, according to double quantum-filtered correlation spectroscopy (DQF-COSY) and GC-MS analysis. Only traces of higher internal and terminal olefins were detected.

The evolution of propene arises exlusively from the initiation reaction of 1-DMSO with ethylene and matches the amount of $\mathrm{Ni}(\mathrm{II})$-ethyl complex 2-DMSO formed. Chain growth occurs from the $\mathrm{Ni}(\mathrm{II})$-alkyl ethylene complexes, which are formed in rapid equilibria with the predominating solvent ( $\mathrm{S}=$ DMSO$d_{6}$ ) complexes (Scheme 1). This is supported by the observation that 2-DMSO was detected as the catalyst resting state exclusively. Figure 3 illustrates a typical time dependence of the conversion of 1-DMSO into 2-DMSO, the consumption of ethylene, and the evolution of propene and butenes.

Notably, the ratio of propene vs butene formation showed that ethylene consumption occurs 1 order of magnitude more rapidly from 2-DMSO than from the reaction with 1-DMSO. Only one-third of the initial concentration of 1-DMSO had reacted to form 2-DMSO after complete ethylene consumption.
Chain transfer occurs to a significantly smaller extent from the primary $\mathrm{Ni}(\mathrm{II})$ - butyl species, as indicated by formation of only a minor amount of 1 -butene $(\sim 15 \%)$. The ratio of 1 -butene vs 2-butene formation is constant until ethylene has been completely consumed, suggesting that the formation of the secondary Ni(II)-butyl DMSO complex is thermodynamically favored.

The clean generation of the neutral $\mathrm{Ni}(\mathrm{II})$-ethyl complex 2-DMSO and its activity in the catalytic dimerization of ethylene in DMSO solution provides a model reaction suitable for studying the influence of water under chain growth conditions. The time-dependent conversion of 1-DMSO into 2-DMSO and formation of propene and butenes in the presence of up to 60 equiv of $\mathrm{D}_{2} \mathrm{O}$ under otherwise identical conditions was followed by ${ }^{1} \mathrm{H}$ NMR spectroscopy. However, no differences in the timedependent consumption and formation of Ni(II)-alkyls, ethylene, and reaction products could be observed (Figure S11 in the Supporting Information). The pseudo-first-order initial rate of the overall ethylene insertion into the $\mathrm{Ni}(\mathrm{II})$-methyl bond of 1-DMSO was found to be independent of the presence of $\mathrm{D}_{2} \mathrm{O}$ (Figure 4). Although trace amounts of $\mathrm{CH}_{3} \mathrm{D}$ were detected, no products from the protolysis (by $\mathrm{D}_{2} \mathrm{O}$ ) of any higher $\mathrm{Ni}-$ alkyl bond were observed.

Preparation and Molecular Dynamics of 2-DMSO. To gain further insight into the reactivity of the $\mathrm{Ni}(\mathrm{II})$-ethyl species, complex 2-DMSO was generated on a preparative scale. Ethylene was bubbled through a DMSO- $d_{6}$ solution of 1-DMSO (14 $\mathrm{mM}$ ) for $45 \mathrm{~min}$ at $50^{\circ} \mathrm{C}$. ${ }^{1} \mathrm{H}$ NMR spectroscopic analysis confirmed the formation of a 3:1 2-DMSO/1-DMSO mixture with negligible amounts of decomposition products. ${ }^{21} \mathrm{~A}$ comprehensive ${ }^{13} \mathrm{C}$ and ${ }^{1} \mathrm{H}$ NMR spectroscopic assignment of 2-DMSO is provided in the Experimental Section. Key ${ }^{1} \mathrm{H}$ and ${ }^{13} \mathrm{C}$ resonances, respectively, of the $\mathrm{Ni}(\mathrm{II})-$ ethyl fragment are observed at -0.42 and $5.0 \mathrm{ppm}$ [Ni(II) $-\mathrm{CH}_{2} \mathrm{CH}_{3}$ ] as well as at -0.07 and $14.7 \mathrm{ppm}\left[\mathrm{Ni}(\mathrm{II})-\mathrm{CH}_{2} \mathrm{CH}_{3}\right]$ at $25^{\circ} \mathrm{C}$ (see above). The signals of the methyl moiety are a somewhat broadened triplet $\left({ }^{3} J_{\mathrm{H}-\mathrm{H}}=7.5 \mathrm{~Hz}\right)$ in the ${ }^{1} \mathrm{H}$ NMR spectrum and a sharp singlet in the proton-decoupled ${ }^{13} \mathrm{C}\left\{{ }^{1} \mathrm{H}\right\}$ NMR spectrum. A severely broadened quartet $\left({ }^{3} J_{\mathrm{H}-\mathrm{H}}=7.5 \mathrm{~Hz}\right)$ was observed for the $\alpha$-methylene protons, and the $\alpha$-carbon resonance is almost completely broadened out into the baseline. The 2D heteronuclear single-quantum correlation (HSQC) NMR spectra verified the assignment of the $\alpha$-carbon chemical shift unambiguously. The typical ${ }^{4} J_{\mathrm{H}-\mathrm{H}}$ coupling of protons $\mathrm{H} 4$ and $\mathrm{H} 6$ of the salicylaldehyde moiety of 2-DMSO was not resolved, whereas the corresponding coupling was observed for 1-DMSO $\left({ }^{4} J_{\mathrm{H}-\mathrm{H}}=2.3 \mathrm{~Hz}\right)$ within the same NMR spectrum (for atom numbering, see eq 1 ). The line width of the corresponding ${ }^{13} \mathrm{C}$ resonance of $\mathrm{C} 4$ at $148.5 \mathrm{ppm}$ was qualitatively estimated to be almost doubled compared with the signal of C6 at 141.5 ppm. Analysis by 2D ROESY NMR spectra revealed that the protons at the $\alpha$ - and $\beta$-carbons undergo chemical exchange.

The spectroscopic data suggest that complex 2-DMSO undergoes two independent dynamic processes that occur at distinct rates on the chemical-shift time scale (Scheme 2). First, $\beta$-hydride elimination, ethylene rotation, and reinsertion cause the chemical exchange of the protons attached to the $\alpha$ - and $\beta$-carbon atoms (Scheme 2a). This process is clearly evident

(21) ${ }^{1} \mathrm{H}$ and ${ }^{13} \mathrm{C}$ NMR spectra revealed that a higher concentration of hexenes was formed under conditions of bubbling ethylene through the reaction solution than under the NMR tube reaction conditions. No reaction products resulting from an ethylene insertion into a secondary Ni(II) - alkyl species were detected. 
Scheme 1. Catalytic Ethylene Dimerization with 1-DMSO in DMSO- $d_{6}$ Solution

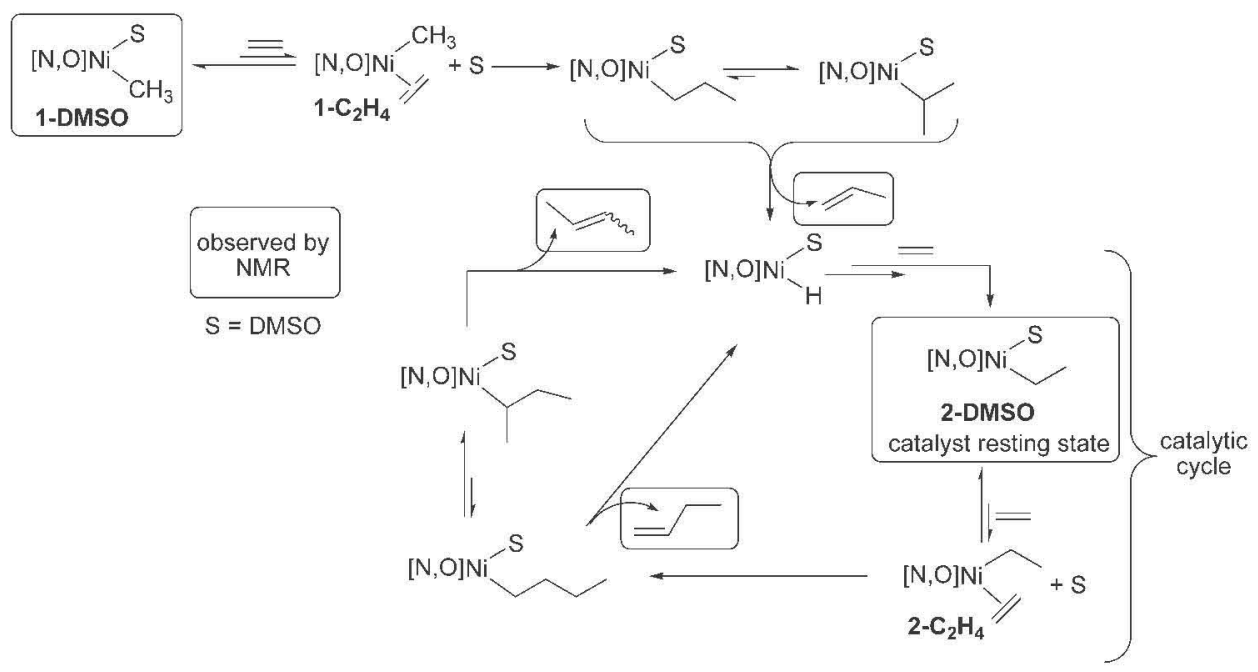

from positive cross-peaks between the $\alpha$-methylene and $\beta$-methyl proton resonances in the 2D ROESY NMR spectra. However, isomerization of the $\mathrm{Ni}(\mathrm{II})$-ethyl moiety by this process occurs slowly on the chemical-shift time scale, as distinct signals are observed in both the ${ }^{1} \mathrm{H}$ and ${ }^{13} \mathrm{C}$ NMR spectra.

Second, rapid cis-trans isomerization causes the substantial broadening of the quartet ${ }^{1} \mathrm{H}$ NMR signal of the $\alpha$-methylene

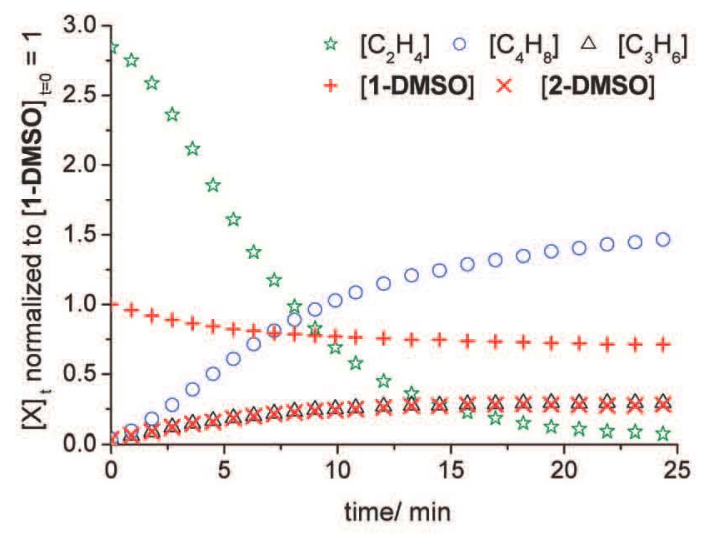

Figure 3. Time-dependence of the formation of $\left[(\mathrm{N}, \mathrm{O}) \mathrm{Ni}\left(\mathrm{C}_{2} \mathrm{H}_{5}\right)(\mathrm{DMSO})\right]$ (2-DMSO) from [(N,O)Ni(CH$)(\mathrm{DMSO})]$ (1-DMSO), the consumption of ethylene, and the formation of the reaction products propene and butene in DMSO- $d_{6}$ at $55^{\circ} \mathrm{C}$ (curves normalized to $[\mathbf{1}-\mathrm{DMSO}]_{t=0}=1$ ).

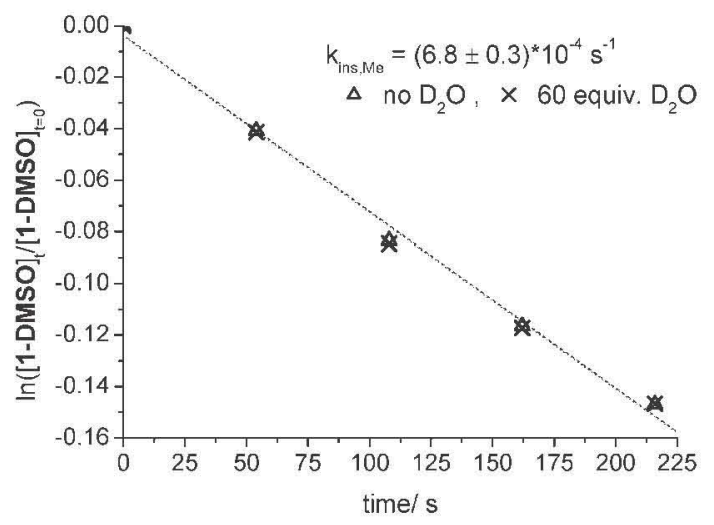

Figure 4. Determination of the initial pseudo-first-order rate constant $k_{\text {ins,Me }}$ for the conversion of 1-DMSO into 2-DMSO after the addition of excess ethylene in the absence $(\Delta)$ and presence $(x)$ of $\mathrm{D}_{2} \mathrm{O}(60$ equiv) at $55^{\circ} \mathrm{C}$.
Scheme 2. Dynamics of 2-DMSO

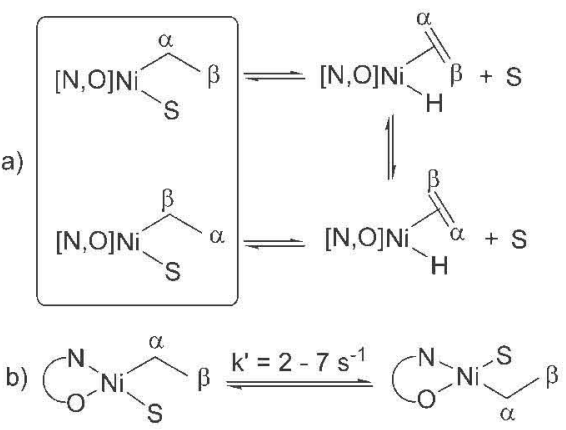

protons and of the $\alpha$-carbon ${ }^{13} \mathrm{C}$ resonance in particular. Protons $\mathrm{H} 4$ and $\mathrm{H} 6$ as well as carbon atoms $\mathrm{C} 4$ and $\mathrm{C} 6$ of the salicylaldiminato ligand are affected by this process. The chemical and magnetic environment is expected to differ considerably between the cis and trans positions as a result of the asymmetry of the salicylaldiminato ligand. A first-order rate constant $k^{\prime}=2-7 \mathrm{~s}^{-1}$ was estimated from the ${ }^{1} \mathrm{H}$ NMR spectra, ${ }^{22}$ which corresponds to a barrier to isomerization of $68-71 \mathrm{~kJ} \mathrm{~mol}^{-1}$ (Scheme 2b).

Decomposition of Neutral Ni(II)-Alkyl Complexes. Decomposition from the Catalyst Precursor. The gradual evolution of ethane from solutions of 1-DMSO in neat DMSO$d_{6}$ was observed at elevated temperatures. ${ }^{23}$ The decrease of the $\mathrm{Ni}(\mathrm{II})-\mathrm{CH}_{3}$ resonance of $1-\mathrm{DMSO}$ was monitored by NMR spectroscopy at temperatures between 55 and $80^{\circ} \mathrm{C}$ (in the absence of water and ethylene). Ethane gave rise to a singlet resonance at $0.83 \mathrm{ppm}$. Its formation was verified by gas chromatography measurements versus a genuine sample of ethane. The kinetic data obtained show that the rate-determining step of the elimination reaction is second order with respect to

(22) The rate of cis-trans isomerization was estimated from the ${ }^{1} \mathrm{H}$ NMR spectra of 2-DMSO. The rate of isomerization is larger than the ${ }^{4} J_{\mathrm{H}-}$ $\mathrm{H}$ coupling frequency of protons $\mathrm{H} 4$ and $\mathrm{H} 6$ (which are therefore unresolved) but smaller than the ${ }^{3} J_{\mathrm{H}-\mathrm{H}}$ coupling frequency of the $\alpha$ and $\beta$-protons of the $\mathrm{Ni}(\mathrm{II})$-ethyl fragment (which are therefore resolved). See the Supporting Information.

(23) Yamamoto and coworkers reported that the neutral Ni(II)-Me complex cis- $\left[(\mathrm{acac}) \mathrm{Ni}\left(\mathrm{CH}_{3}\right)\left(\mathrm{PPh}_{3}\right)_{2}\right]$ produced methane and ethane (in a ratio of $1: 2$ ) upon thermolysis at $120^{\circ} \mathrm{C}$. See: Yamamoto, A.; Yamamoto, T.; Saruyama, T.; Nakamura, Y. J. Am. Chem. Soc. 1973, 95, 40734074. 


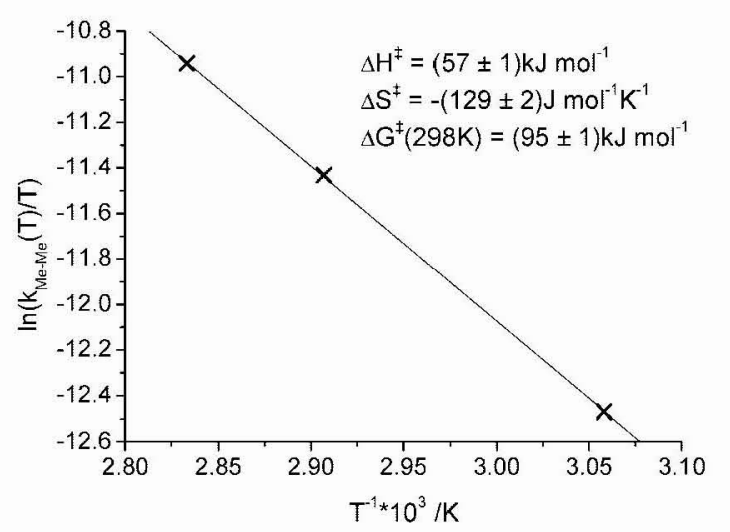

Figure 5. Eyring plot of the observed rate constants $k_{\mathrm{Me}-\mathrm{Mc}}(T)$ for decomposition of 1-DMSO to $\mathrm{C}_{2} \mathrm{H}_{6}$ in DMSO- $d_{6}$ (as determined from the decrease of the $\mathrm{Ni}(\mathrm{II})-\mathrm{CH}_{3}$ resonance in the temperature range from 55 to $\left.80^{\circ} \mathrm{C}\right) .{ }^{24}$

Scheme 3. Proposed Mechanism for Bimolecular Elimination of $\mathrm{C}_{2} \mathrm{H}_{6}$ from 1-DMSO

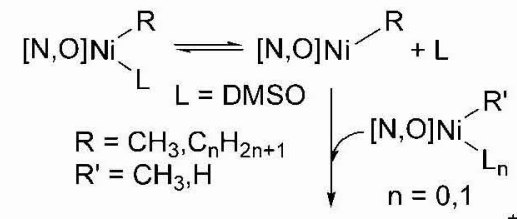

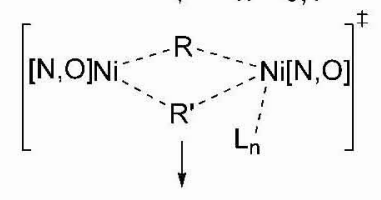

1-DMSO (Figure S12 in the Supporting Information). Determination of $k_{\mathrm{Me}-\mathrm{Me}}(T)$ over the temperature range $55-80{ }^{\circ} \mathrm{C}$ yields an activation enthalpy of $\Delta H^{+}=(57 \pm 1) \mathrm{kJ} \mathrm{mol}^{-1}$ and an activation entropy of $\Delta S^{\ddagger}=-(129 \pm 2) \mathrm{J} \mathrm{mol}^{-1} \mathrm{~K}^{-1}$, corresponding to a free energy of activation of $\Delta G^{\ddagger}(298 \mathrm{~K})=$ $(95 \pm 1) \mathrm{kJ} \mathrm{mol}^{-1}$ (Figure 5). ${ }^{24}$ Notably, strongly coordinating ligands stabilize the $\mathrm{Ni}(\mathrm{II})-$ methyl fragment, i.e., no decomposition of the corresponding pyridine derivative 1-pyr to ethane was observed over several hours at $80{ }^{\circ} \mathrm{C}$ in DMSO- $d_{6}$ solution. 1-DMSO slowly degraded in neat $\mathrm{CD}_{2} \mathrm{Cl}_{2}$ solution even at ambient temperature, whereas no degradation was observed in DMSO solution under the same conditions over several days.

The mechanistic scenario depicted in Scheme 3 accounts for the observations that strongly coordinating ligands prevent the $\mathrm{Ni}(\mathrm{II})$ - methyl species from degradating to ethane efficiently and that the rate-determining step is bimolecular in 1-DMSO. An intermediate methyl-bridged homodinuclear species likely occurs. Mechanistic studies of exchange reactions of alkyl fragments between transition-metal-alkyl complexes have shown that alkyl migration occurs via carbon-bridged homoor heterodinuclear metal species that are formed in a bimolecular rate-determining reaction step. The facility of alkyl exchange strongly depends on the nature of the migrating alkyl fragment. ${ }^{25}$

The dimerization of two $\mathrm{Ni}(\mathrm{II})$-methyl species bearing sterically demanding substituents on the framework of the $(\mathrm{N}, \mathrm{O})$

(24) This temperature interval was chosen because the rates of the reaction are in a reasonable range for accurate determination.

(25) (a) Bryndza, H. E.; Evitt, E. R.; Bergman, R. G. J. Am. Chem. Soc. 1980, 102, 4948-4951. (b) Collman, J. P.; Brauman, J. I.; Madonik, A. M. Organometallics 1986, 5, 215-218. ligand should clearly be unfavorable in terms of entropy. Indeed, the observed activation entropy for this process is negative and contributes significantly to the activation barrier of the reaction, which supports the suggested mechanistic scenario (Scheme 3). Literature examples of truly bimolecular carbon-carbon bond elimination reactions from metal-alkyls are rare but support the assumption of transient dinuclear metal complexes. ${ }^{26}$

Decomposition Pathways Involving Higher Ni(II)-Alkyl Species. The active species in $\mathrm{C}-\mathrm{C}$ linkage reactions of olefins are higher metal-alkyls, in this case the neutral $\mathrm{Ni}(\mathrm{II})-$ alkyls $\left[(\mathrm{N}, \mathrm{O}) \mathrm{Ni}\left\{\left(\mathrm{CH}_{2} \mathrm{CH}_{2}\right)_{n} \mathrm{H}\right\}\right]$. Their reactivities can differ substantially from that of the $\mathrm{Ni}$ (II) - methyl species employed as catalyst precursor, as also exemplified by the different rates of olefin insertion outlined above.

The amenity of 2-DMSO to hydrolysis of the $\mathrm{Ni}(\mathrm{II})$-carbon bond was studied by adding $\sim 700$ equiv of water $\left(\mathrm{D}_{2} \mathrm{O}\right)$ to a DMSO- $d_{6}$ solution containing a typical $3: 1$ mixture of the $\mathrm{Ni}(\mathrm{II})$-alkyls 2-DMSO and 1-DMSO (obtained from bubbling ethylene through a DMSO- $d_{6}$ solution of 1-DMSO, as described above; no residual free ethylene was present) at room temperature in an NMR tube. In agreement with the aforementioned independence of the progress of ethylene dimerization of the presence of water, no detectable quantity of the expected hydrolysis product, monodeuteroethane $\left(\mathrm{C}_{2} \mathrm{H}_{5} \mathrm{D}\right)$, was observed even over prolonged periods of time $(\geq 12 \mathrm{~h})$ at ambient temperature. However, significant amounts of $\mathrm{CH}_{4}$ and $\mathrm{C}_{2} \mathrm{H}_{6}$ were detected in addition to minor amounts of $\mathrm{CH}_{3} \mathrm{D}\left(\mathrm{CH}_{4} /\right.$ $\mathrm{CH}_{3} \mathrm{D}$ ratio $\approx 5: 1$ ), the latter being formed from the hydrolysis $\left(\mathrm{D}_{2} \mathrm{O}\right)$ of the precursor $\mathrm{Ni}(\mathrm{II})-$ methyl complex. The gradual evolution of $\mathrm{CH}_{4}$ and $\mathrm{C}_{2} \mathrm{H}_{6}$ was also observed from a nonaqueous NMR sample. The formation of $\mathrm{CH}_{4}$ suggests that bimolecular deactivation pathways that involve not only $\mathrm{Ni}(\mathrm{II})-$ alkyl speciesbut also $\mathrm{Ni}$ (II) -hydride species are operative. $\mathrm{Ni}$ (II) - hydride species are key intermediates in the $\mathrm{C}-\mathrm{C}$ linkage of ethylene (in dimerization, oligomerization, and polymerization processes) and also in the isomerization of the $\mathrm{Ni}(\mathrm{II})$-ethyl complex 2-DMSO (Schemes 1 and 2). ${ }^{27}$

The novel neutral $\mathrm{Ni}(\mathrm{II})$-hydride complex $\left[(\mathrm{N}, \mathrm{O}) \mathrm{NiH}\left(\mathrm{PMe}_{3}\right)\right]$ (3-PMe $\mathbf{P}_{3}$ ) was synthesized independently to directly study the reaction between a $\mathrm{Ni}(\mathrm{II})$-alkyl and a $\mathrm{Ni}(\mathrm{II})$-hydride species. Key ${ }^{1} \mathrm{H}$ NMR chemical shifts of $3-\mathrm{PMe}_{3}$ in $\mathrm{CD}_{2} \mathrm{Cl}_{2}$ solution are $7.63 \mathrm{ppm}\left(-\mathrm{HC}=\mathrm{N}-,{ }^{4} J_{\mathrm{H}-\mathrm{P}}=8.5 \mathrm{~Hz}\right), 1.24 \mathrm{ppm}$ $\left[\mathrm{Ni}(\mathrm{II})-\mathrm{P}\left(\mathrm{CH}_{3}\right)_{3},{ }^{2} J_{\mathrm{H}-\mathrm{P}}=10.6 \mathrm{~Hz}\right]$, and $-26.96 \mathrm{ppm}[\mathrm{Ni}(\mathrm{II})-\mathrm{H}$, $\left.{ }^{2} J_{\mathrm{H}-\mathrm{P}}=142.5 \mathrm{~Hz}\right]$. From a $\mathrm{CD}_{2} \mathrm{Cl}_{2}$ solution of 1-DMSO and

(26) (a) Ozawa, F.; Fujimori, M.; Yamamoto, T.; Yamamoto, A. Organometallics 1986, 5, 2144-2149. (b) Goj, L. A.; Blue, E. D.; Delp, S. A.; Gunnoe, T. B.; Cundary, T. R.; Petersen, J. L. Organometallics 2006, $25,4097-4104$.

(27) The eliminations of aldehydes and alkanes from the intermolecular reaction of transition-metal carbonyl hydrides with metal carbonyl alkyl or acyl complexes are well-understood examples of intermolecular elimination reactions that reflect the unique ability of hydride ligands to bridge-pair transition-metal atoms. These reactions have been intensely studied in the context of the catalytic hydroformylation of olefins with $\mathrm{CO}$. Hydride-bridged homo- or heterodinuclear metal species, $\left[[\mathrm{M}] \mathrm{R}-\mu^{2}-\mathrm{H}-\left[\mathrm{M}^{\prime}\right]\right]\{\mathrm{R}=\mathrm{C}(\mathrm{O})$ alkyl, alkyl; $[\mathrm{M}]=$ metal carbonyl fragment\}, are assumed to be key intermediates from which the elimination products are formed in an intramolecular reaction step. For an early discussion of organometallic elimination mechanisms, see: (a) Norton, J. R. Acc. Chem. Res. 1979, 12, 139-145. For further mechanistic studies on (non-radical) bimolecular elimination reactions producing aldehydes or alkanes, see: (b) Jones, W. D.; Huggins, J. M.; Bergman, R. G. J. Am. Chem. Soc. 1981, 103, 4415-4423. (c) Nappa, M. J.; Santi, R.; Halpern, J. Organometallics 1985, 4, 34-41. (d) Martin, B. D.; Warner, K. E.; Norton, J. R. J. Am. Chem. Soc. 1986, 108, 33-39. (e) Li, C.; Chen, L.; Garland, M. J. Am. Chem. Soc. 2007, $129,13327-13334$. 


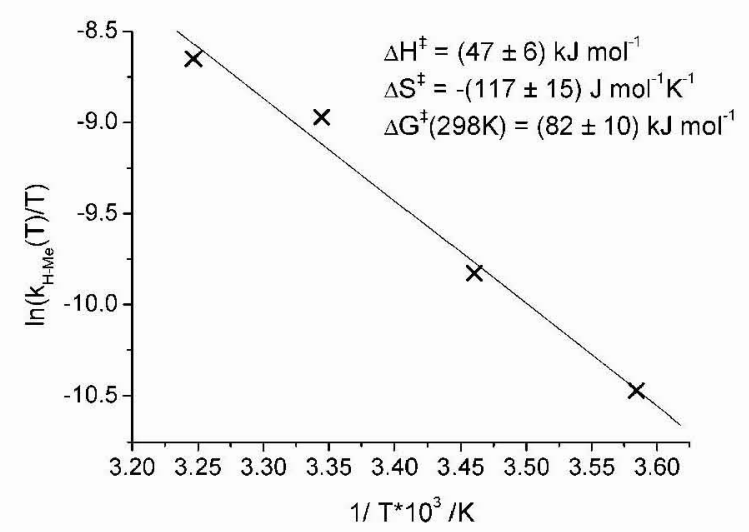

Figure 6. Eyring plot of the observed second-order rate constants $k_{\mathrm{H}-\mathrm{Me}}(T)$ for methane formation from 1-DMSO and $\mathbf{3 - P M e}$ in $\mathrm{CD}_{2} \mathrm{Cl}_{2}$ (temperature range $6-36{ }^{\circ} \mathrm{C}$ ).

excess 3-PMe 3 [11.5 mM 3-PMe 3 , 1.4 equiv of $\mathrm{Ni}(\mathrm{II})-\mathrm{H}$ species per $\mathrm{Ni}(\mathrm{II})-\mathrm{CH}_{3}$ species], $\mathrm{CH}_{4}$ (singlet at $0.20 \mathrm{ppm}$ ) was indeed gradually formed. It should be noted that during the course of the reaction, a portion of 1-DMSO underwent immediate ligand exchange with $\mathrm{PMe}_{3}$ liberated by decomposition of 3-PMe 3 (see below) to afford 1-PMe ylphosphine was observed. Furthermore, a black precipitate, presumably Ni-black, was formed. The formation of 1-PMe was monitored from its characteristic resonances at $1.12 \mathrm{ppm}$ (d, $\left.\mathrm{Ni}(\mathrm{II})-\mathrm{P}\left(\mathrm{CH}_{3}\right)_{3},{ }^{2} J_{\mathrm{H}-\mathrm{P}}=10.4 \mathrm{~Hz}\right)$ and $-1.37 \mathrm{ppm}(\mathrm{d}$, $\mathrm{Ni}(\mathrm{II})-\mathrm{CH}_{3},{ }^{3} \mathrm{~J}_{\mathrm{H}-\mathrm{P}}=7.1 \mathrm{~Hz}$ ). Monitoring of the $\mathrm{Ni}(\mathrm{II})-\mathrm{CH}_{3}$ and $\mathrm{Ni}(\mathrm{II})-H$ resonances over time by variable-temperature ${ }^{1} \mathrm{H}$ NMR spectroscopy revealed that the rate-determining step is bimolecular with the rate law $r=k_{\mathrm{H}-\mathrm{Me}}(T)$ [1-DMSO][3-PMe 3 ] (see the Supporting Information). Determination of $k_{\mathrm{H}-\mathrm{Me}}(T)$ over the temperature range $6-35{ }^{\circ} \mathrm{C}$ yielded $\Delta H^{+}=(47 \pm 6)$ $\mathrm{kJ} \mathrm{mol}^{-1}$ and $\Lambda S^{\ddagger}=-(117 \pm 15) \mathrm{J} \mathrm{mol}^{-1} \mathrm{~K}^{-1}$ (Figure 6), corresponding to $\Delta G^{\ddagger}=(82 \pm 10) \mathrm{kJ} \mathrm{mol}^{-1}$ at room temperature.

A comparison to the activation parameters determined for the bimolecular elimination of ethane from 1-DMSO suggests that the two processes follow an essentially similar mechanism (Scheme 3, $\mathrm{R}=\mathrm{CH}_{3}, \mathrm{R}^{\prime}=\mathrm{H}$ ). The obtained reaction entropies are comparable to data determined for the elimination of propanal from the reaction of $\left[\mathrm{EtC}(\mathrm{O}) \operatorname{Re}(\right.$ acetonitrile $\left.)(\mathrm{CO})_{4}\right]$ with metal carbonyl hydrides $[\mathrm{H}[\mathrm{M}]]^{27 d}$

To differentiate between ethane formation from a crosscoupling reaction between a $\mathrm{Ni}(\mathrm{II})$-hydride species and 2-DMSO and a homo-cross-coupling process involving 1-DMSO, complex 3-PMe 3 was dissolved in a DMSO- $d_{6}$ solution containing the Ni(II)-alkyls 2-DMSO and 1-DMSO in a 3:1 ratio and no free ethylene. ${ }^{1} \mathrm{H}$ NMR spectra acquired immediately after sample preparation revealed the formation of a mixture of the

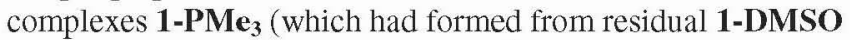
in a ratio of $12: 1$ ), 2-PMe 3 [the key ${ }^{1} \mathrm{H}$ NMR chemical shifts of the $\mathrm{Ni}(\mathrm{II})$-ethyl fragment are the following: $-0.78 \mathrm{ppm}$, quintet, $\mathrm{Ni}(\mathrm{II})-\mathrm{CH}_{2} \mathrm{CH}_{3} ; 0.34 \mathrm{ppm}$, multiplet, $\left.\mathrm{Ni}(\mathrm{II})-\mathrm{CH}_{2} \mathrm{CH}_{3}\right]$ and 2-DMSO in a 1:1 ratio, and $\mathbf{3}-\mathbf{P M e}_{3}$; the total $\mathrm{Ni}(\mathrm{II})-$ alkyl/ $\mathrm{Ni}(\mathrm{II})-H$ ratio was $2: 1$, while the ratio of $\mathrm{Ni}(\mathrm{II})$ - ethyl to $\mathrm{Ni}(\mathrm{II})-$ methyl complexes was still 3:1. No resonances of either ethane or methane and no $\mathrm{Ni}$ (II)-hydride resonances other than that of $\mathbf{3}-\mathbf{P M e}_{3}$ were observed in the freshly prepared sample.

The disappearance of $\mathrm{Ni}(\mathrm{II})$-alkyl and $\mathrm{Ni}$ (II)-hydride resonances was followed over time by ${ }^{1} \mathrm{H}$ NMR spectroscopy at room temperature. Integration versus free DMSO- $h_{6}$ as an internal standard showed that resonances due to the DMSO- coordinated Ni-alkyls 1-DMSO and 2-DMSO gradually decreased as the signals of ethane and methane gradually grew in (Figure S9 in the Supporting Information). Homocoupling of 1-DMSO alone could not account for the amount of $\mathrm{C}_{2} \mathrm{H}_{6}$ formed, independently confirming that cross-coupling also occurs between higher $\mathrm{Ni}$ (II)-alkyl and $\mathrm{Ni}(\mathrm{II})$-hydride species. The gradual formation of ethane was also observed from a THF solution of 2-PMe 3 prepared in situ from $\mathbf{3}-\mathbf{P M e}_{3}$ with ethylene at $-10{ }^{\circ} \mathrm{C}$ (Figure S10 in the Supporting Information).

The perdeuterated $\mathrm{Ni}(\mathrm{II})$-ethyl complex $\mathbf{2}_{\mathrm{d}}$-DMSO was prepared analogously to 2-DMSO by reaction of 1-DMSO with $\mathrm{D}_{2} \mathrm{C}=\mathrm{CD}_{2}$ in DMSO- $d_{6}$ solution at $50{ }^{\circ} \mathrm{C}$. Samples that also contained $\sim 6$ and $>500$ equiv of water $\left(\mathrm{H}_{2} \mathrm{O}\right)$ per $\mathrm{Ni}-$ alkyl $\left(\mathbf{1}-\mathrm{DMSO} / \mathbf{2}_{\mathbf{d}}\right.$-DMSO ratio $\left.\approx 1: 1\right)$ were also prepared. The gradual formation of $\mathrm{C}_{2} \mathrm{H}_{6}$ (singlet at $0.81 \mathrm{ppm}$ ) and $1,1,1,2,2$ pentadeuteropropane $\mathrm{C}_{3} \mathrm{H}_{3} \mathrm{D}_{5}\left(0.85 \mathrm{ppm}\right.$, quintet, $\left.{ }^{3} J_{\mathrm{HD}} \approx 1.2 \mathrm{~Hz}\right)$ was monitored by ${ }^{1} \mathrm{H}$ NMR spectroscopy for both samples over the course of 3 days at $25^{\circ} \mathrm{C}$, the ratio being $\sim 1: 5$ irrespective of the amount of water in the system (Figure S8 in the Supporting Information). 1,1,1,2,2-Pentadeuteropropane is the product of the cross-coupling reaction of $\mathbf{1 - D M S O}$ and $\mathbf{2}_{\mathrm{d}}$ DMSO, whereas $\mathrm{C}_{2} \mathrm{H}_{6}$ is formed solely from 1-DMSO. To address the question of butane formation from homo-crosscoupling of 2-DMSO, a sample containing a mixture of 2-DMSO and $\mathbf{2}_{\mathrm{d}}$-DMSO in a $2: 1$ ratio was prepared (this strategy was pursued because the presence or absence of butane, $\mathrm{C}_{4} \mathrm{H}_{10}$, was difficult to prove with sufficient accuracy in the presence of the butenes originating from ethylene dimerization). Standard ${ }^{1} \mathrm{H}$, deuterium-decoupled ${ }^{1} \mathrm{H}\left\{{ }^{2} \mathrm{H}\right\}$, and ${ }^{2} \mathrm{H}$ NMR spectra were acquired, but no evidence of the formation of either butane or 1,1,1,2,2-pentadeuterobutane was obtained from any of these spectra, even after complete decomposition of the $\mathrm{Ni}(\mathrm{II})-$ alkyls. This suggests that homo-cross-coupling of higher Ni(II)-alkyls either does not occur at all or is slow compared with coupling pathways with $\mathrm{Ni}(\mathrm{II})$-hydride and the $\mathrm{Ni}(\mathrm{II})$ - methyl catalyst precursor. $^{28}$

Notably, the formation of small quantities of $\mathrm{CH}_{3} \mathrm{D}$ was observed by ${ }^{1} \mathrm{H}$ NMR spectroscopy for all samples containing a mixture of the complexes 1-DMSO and $\mathbf{2}_{\mathbf{d}}$-DMSO. This results from the reaction of a $\mathrm{Ni}(\mathrm{II})-$ methyl species of residual 1-DMSO with $\mathrm{Ni}(\mathrm{II})-\mathrm{D}$ species, which are in equilibrium with deuterium-labeled $\mathbf{2}_{\mathbf{d}}$-DMSO (see Scheme 2). In the presence of larger amounts of $\mathrm{H}_{2} \mathrm{O}, \mathrm{CH}_{4}$ was also observed, resulting from the hydrolysis of unreacted 1-DMSO. A weak broad resonance at $0.75 \mathrm{ppm}$ might correspond to the formation of pentadeuteroethane $\mathrm{C}_{2} \mathrm{D}_{5} \mathrm{H}$, the hydrolysis product of $\mathbf{2}_{\mathrm{d}}$-DMSO and $\mathrm{H}_{2} \mathrm{O}$. As observed for the $\mathrm{Ni}(\mathrm{II})$ - methyl species employed as a catalyst precursor, hydrolysis is not the dominant deactivation pathway for the catalytically active higher $\mathrm{Ni}$ (II)-alkyls.

\section{Summary and Conclusions}

The DMSO-coordinated Ni(II)-methyl salicylaldiminato complex 1-DMSO is a suitable precursor for mechanistic studies of deactivation routes of neutral Ni(II) catalysts. In DMSO as

(28) In the context of the apparently neglible tendencies for bimolecular homocoupling of higher $\mathrm{Ni}(\mathrm{II})-$ alkyls, it is interesting to take note of the studies on alkyl exchange reactions reported in ref $25 \mathrm{~b}$. Facile alkyl exchange between Rh(I)-alkyls was limited to methyl and benzyl fragments, whereas higher alkyls, either primary or secondary, did not undergo any observable exchange. If it is assumed that the mechanisms for alkyl exchange and intermolecular elimination reactions are similar, the preference for alkyl homocoupling observed by us would appear to reflect the distinct reactivity of the Ni(II)-methyl catalyst precursor compared with that of higher $\mathrm{Ni}(\mathrm{II})-$ alkyls. 
a solvent, activation of 1-DMSO as a catalyst precursor and catalytic $\mathrm{C}-\mathrm{C}$ linkage of ethylene can be observed directly by ${ }^{1} \mathrm{H}$ NMR spectroscopy. In these experiments $\left(55^{\circ} \mathrm{C}\right.$, initial ethylene concentration $\approx 0.15 \mathrm{~mol} \mathrm{~L}^{-1}$ ), a minor but sufficient portion of 1-DMSO is transformed into the active species by insertion of ethylene and subsequent elimination of propylene. Ethylene is consumed by catalytic dimerization to butenes. The observed catalyst resting state is the ethyl complex 2-DMSO. Studies of the dynamics of 2-DMSO reveal the occurrence of two different processes. Isomerization of the position of the alkyl group and the DMSO ligand results in exchange of these ligands between the positions cis and trans to the $\mathrm{O}$-donor and $\mathrm{N}$-donor, respectively, of the salicylaldiminato ligand. More importantly in the context of these studies, exchange of the $\alpha$ - and $\beta$-carbon atoms of the ethyl moiety occurs via $\beta$-hydride elimination to a hydride-olefin complex (not observed) and olefin rotation prior to reinsertion.

Added $\mathrm{D}_{2} \mathrm{O}$ does not significantly influence the rate of either the aforementioned activation reaction or catalytic dimerization. This implies that water does not significantly coordinate to the metal center (or otherwise impede the reaction), in accordance with the fact that the conceivable water complexes $[(\mathrm{N}, \mathrm{O})$ $\mathrm{Ni}$ (alkyl)(water)] were not observed. Hydrolysis of the $\mathrm{Ni}(\mathrm{II})-\mathrm{Me}$ moiety of the catalyst precursor is evidenced by the formation of $\mathrm{CH}_{3} \mathrm{D}$, but no hydrolysis of the higher (R > Me) $\mathrm{Ni}(\mathrm{II})$-alkyls occurring during chain growth was observed. Overall, hydrolysis of $\mathrm{Ni}(\mathrm{II})$-alkyl species appears to be a minor decomposition reaction compared with the significant water-independent decomposition reactions. These were found to be the reductive elimination of alkanes by reaction of $\mathrm{Ni}(\mathrm{II})$-alkyl species with $\mathrm{Ni}(\mathrm{II})$-hydride [Ni(II) $-\mathrm{R}+\mathrm{Ni}(\mathrm{II})-\mathrm{H} \rightarrow \mathrm{RH}]$ and also by reaction of two molecules of the $\mathrm{Ni}(\mathrm{II})-\mathrm{Me}$ catalyst precusor species [2Ni(II)- $\mathrm{Me} \rightarrow \mathrm{C}_{2} \mathrm{H}_{6}$ ]. Thus, reaction of 1-DMSO with the separately prepared novel hydride complex $\mathbf{3}-\mathbf{P M e}_{3}$ affords $\mathrm{CH}_{4}$ as a product. Kinetic studies demonstrate the reaction to be first order in both 1-DMSO and 3-PMe $\mathbf{P}_{3}$, that is, the decisive step is bimolecular $\left[\Delta H^{\ddagger}=(47 \pm 6) \mathrm{kJ} \mathrm{mol}^{-1}\right.$ and $\Delta S^{\ddagger}=-(117$ $\pm 15) \mathrm{J} \mathrm{mol}^{-1} \mathrm{~K}^{-1}$. Evolution of $\mathrm{C}_{2} \mathrm{H}_{6}$ from solutions of the ethyl complex 2-DMSO, the occurrence of which can be explained only by reaction of the ethyl complex with $\mathrm{Ni(II)-H}$ species, with which the ethyl complex is always in equlibrium (see above), demonstrates that higher $\mathrm{Ni}(\mathrm{II})$-alkyls also react with $\mathrm{Ni}(\mathrm{II})-\mathrm{H}$. The latter two represent the active species in the $\mathrm{C}-\mathrm{C}$ linkage (oligomerization or polymerization) of olefins. That is, the reaction $\mathrm{Ni}(\mathrm{II})-\mathrm{R}+\mathrm{Ni}(\mathrm{II})-\mathrm{H} \rightarrow \mathrm{RH}$ is a decomposition pathway intrinsic to the neutral $\mathrm{Ni}$ (II) catalysts studied. These findings are in line with the previous suggestion that bulky substituted salicylaldiminato ligands hinder catalyst decomposition. ${ }^{8 \mathrm{f}, 16}$ Decomposition of the precursor 1-DMSO in the absence of other reagents yields $\mathrm{C}_{2} \mathrm{H}_{6}$ in a bimolecular reaction $\left[\Delta H^{\ddagger}=(57 \pm 1) \mathrm{kJ} \mathrm{mol}^{-1}\right.$ and $\Delta S^{\ddagger}=-(129 \pm 2) \mathrm{J}$ $\mathrm{mol}^{-1} \mathrm{~K}^{-1}$ ]. Reductive coupling of 1-DMSO with the ethyl complex 2-DMSO to form propane was also observed, but no homocoupling of the higher Ni(II)-alkyl 2-DMSO.

In summary, these studies demonstrate for the first time that bimolecular elimination of alkane from reaction of $\mathrm{Ni}(\mathrm{II})$-alkyl species with $\mathrm{Ni}(\mathrm{II})$-hydride, which are both intermediates of the catalytic cycle, is the major deactivation route in the neutral $\mathrm{Ni}(\mathrm{II})$ catalysts studied. This provides a rationale for catalyst design and for an appropriate choice of reaction conditions that provide site isolation. In comparison, water as the most ubiquitous polar impurity (and also a component of emulsion systems) accounts for catalyst decomposition to only a very minor extent under the conditions studied.

\section{Experimental Section}

All manipulations of air- and moisture-sensitive substances were carried out using standard Schlenk, vacuum, and glovebox techniques under argon or nitrogen. Deuterated solvents (purity and degree of deuteration $\geq 99.5 \%$ ) were purchased from Eurisotop. All of the solvents were thoroughly degassed and saturated with argon prior to use. DMSO was distilled from $4 \AA$ molecular sieves, dichloromethane from $\mathrm{P}_{2} \mathrm{O}_{5}$, and methanol from magnesium turnings. Toluene was dried and deoxygenized by passage through columns containing activated molecular sieves and a BASF R3-11 catalyst. Triethylamine was distilled from potassium hydroxide and degassed and stored under argon. The salicylaldimine $[\mathrm{N}, \mathrm{O}] \mathrm{H}$, i.e., $1-\mathrm{C}(\mathrm{H})=\mathrm{NAr}-2-(\mathrm{OH})-3,5-\mathrm{I}_{2}-\mathrm{C}_{6} \mathrm{H}_{2}\left(\mathrm{Ar}=2,6-\left\{3,5-\left(\mathrm{F}_{3} \mathrm{C}\right)_{2} \mathrm{C}_{6} \mathrm{H}_{3}\right\}_{2^{-}}\right.$ $\left.\mathrm{C}_{6} \mathrm{H}_{3}\right)$, and $\left[\mathrm{NiCl}_{2}\left(\mathrm{PMe}_{3}\right)_{2}\right]$ were prepared by modification of reported procedures. ${ }^{81,29}$ [(Tmeda) $\mathrm{NiMe}_{2}$ ] was purchased from MCAT and stored at $-30^{\circ} \mathrm{C}$ in a glovebox. Sodium trimethoxyborohydride was purchased from Sigma-Aldrich as $>90 \%$ technical grade. It was extracted three times with diethyl ether, dried under high vacuum, and stored in a glovebox. NMR spectra were recorded on a Varian Inova 400 or a Bruker Avance DRX 600 instrument. ${ }^{1} \mathrm{H}$ chemical shifts were referenced to residual proton resonances of the solvent. ${ }^{13} \mathrm{C}$ chemical shifts were referenced to the deuterated solvent. The assignments of chemical shifts are based on ${ }^{1} \mathrm{H}$, ${ }^{13} \mathrm{C}\left\{{ }^{1} \mathrm{H}\right\},{ }^{1} \mathrm{H},{ }^{1} \mathrm{H}-\mathrm{DQF}-\mathrm{COSY},{ }^{1} \mathrm{H},{ }^{13} \mathrm{C}-\mathrm{HSQC},{ }^{1} \mathrm{H},{ }^{13} \mathrm{C}$ gradient heteronuclear multiple-bond correlation ( $\mathrm{gHMBC}$ ), and ${ }^{1} \mathrm{H},{ }^{1} \mathrm{H}$-ROESY NMR spectroscopic experiments. In general, variable-temperature NMR spectroscopic experiments were carried out with prior temperature determination using a sample of neat methanol or ethylene glycol. Ethylene of 3.5 grade supplied by Gerling, Holz $\&$ Co was used as received. Ethylene- $d_{4}$ (chemical purity $>98 \%$, isotope enrichment $>99 \%$ ) was purchased from Eurisotop (Cambridge Isotope Laboratories) and used as received. Gel permeation chromatography (GPC) was carried out in 1,2,4-trichlorobenzene/ $0.0125 \% \mathrm{BHT}$ at $160^{\circ} \mathrm{C}$ at a flow rate of $1 \mathrm{~mL} \mathrm{~min}{ }^{-1}$ on a Polymer Laboratories 220 instrument equipped with Olexis columns with differential refractive index, viscosity, and light-scattering (15 and $90^{\circ}$ ) detectors. Data reported were determined via triple detection employing the PL GPC-220 software algorithm. As the instrument recorded light scattering at only two angles, the data analysis involved an iteration for the calculation of molecular weights and form factors for each measured interval. The instrument was calibrated with narrow polystyrene and polyethylene standards. Data given are referenced to linear polyethylene. Differential scanning calorimetry (DSC) was performed using a Netzsch DSC 204 F1 instrument with a heating/cooling rate of $10 \mathrm{~K} \mathrm{~min}^{-1}$. DSC data reported are from second heating cycles. Gaseous reaction products were characterized by gas chromatography using mass (HP 6890 Series GC, HP 5973 Mass Selective Detector) and flame-ionization detection (Thermo Finnigan, TraceGC). Each of the gas chromatographs was equipped with a Phenomenex ZB-5 ms w/Guardian capillary column $(30 \mathrm{~m} \times 0.25 \mathrm{~mm} \times 0.25 \mu \mathrm{m})$. Helium of $99.995 \%$ purity was used as the carrier gas. The initial temperature of $30^{\circ} \mathrm{C}$ was kept for $6 \mathrm{~min}$, after which the column was heated at a rate of $20{ }^{\circ} \mathrm{C} \mathrm{min}-1$ up to $280{ }^{\circ} \mathrm{C}$. The final temperature was kept for $5 \mathrm{~min}$.

Preparation of [(N,O)NiMe(DMSO)] (1-DMSO). In a glovebox, a dry Schlenk flask was charged with $119 \mathrm{mg}(0.58 \mathrm{mmol})$ of [(tmeda) $\left.\mathrm{NiMe}_{2}\right]$. A $10 \mathrm{~mL}$ aliquot of degassed DMSO $\left(\mathrm{H}_{2} \mathrm{O}<50\right.$ $\mathrm{ppm}$ ) was added to afford a greenish-yellow solution. A solution of $501 \mathrm{mg}(0.58 \mathrm{mmol})$ of the salicylaldimine $[\mathrm{N}, \mathrm{O}] \mathrm{H}$ in $10 \mathrm{~mL}$ of DMSO was added dropwise through a rubber septum. The reaction solution immediately turned dark-red, and evolution of methane was observed. After the complete addition of the ligand solution, the reaction mixture was stirred for an additional $20 \mathrm{~min}$. The flask

(29) Dahl, O. Acta Chem. Scand. 1969, 23, 2342-2354. 
was removed from the glovebox and warmed to $35^{\circ} \mathrm{C}$ in a water bath, and DMSO was completely evaporated under high vacuum via an air-cooled transfer bridge into a flask submerged in liquid nitrogen. The red residue was repeatedly treated with fresh portions of DMSO $(3 \times 20 \mathrm{~mL})$ and brought to dryness to afford a red powder. The solid was extracted with $3 \mathrm{~mL}$ of methanol at -80 ${ }^{\circ} \mathrm{C}$ and rapidly collected onto a dry filter frit under argon at room temperature. The orange-red solid obtained was dried under high vacuum to yield $333 \mathrm{mg}(0.33 \mathrm{mmol}, 56 \%$ ) of 1-DMSO (for numbering of atoms, see eq 1). Anal. Calcd for $\mathrm{C}_{32} \mathrm{H}_{21} \mathrm{~F}_{12} \mathrm{I}_{2} \mathrm{NO}_{2} \mathrm{SNi}$ : C, 37.53; H, 2.07; N, 1.37. Found: C, 37.45; H, 2.25; N, 1.40 .

${ }^{1} \mathrm{H}$ NMR (DMSO- $d_{6}, 400 \mathrm{MHz}$ ): $\delta 8.25$ (br s, $2 \mathrm{H}, \mathrm{H} 18,26$ ); 8.21 (br s, $4 \mathrm{H}, \mathrm{H} 15,21,23,29) ; 8.13$ (s, $1 \mathrm{H}, \mathrm{H} 7) ; 7.90\left(\mathrm{~d},{ }^{4} J_{\mathrm{H}-\mathrm{H}}\right.$ $=2.3 \mathrm{~Hz}, 1 \mathrm{H}, \mathrm{H} 4) ; 7.68\left(\mathrm{~d},{ }^{3} \mathrm{~J}_{\mathrm{H}-\mathrm{H}}=7.6 \mathrm{~Hz}, 2 \mathrm{H}, \mathrm{H} 10,12\right) ; 7.54$ $\left(\mathrm{dd},{ }^{3} J_{\mathrm{H}-\mathrm{H}}=7.6 \mathrm{~Hz}, 1 \mathrm{H}, \mathrm{H} 11\right) ; 7.38\left(\mathrm{~d},{ }^{4} J_{\mathrm{H}-\mathrm{H}}=2.3 \mathrm{~Hz}, 1 \mathrm{H}, \mathrm{H} 6\right)$; $2.54\left(\mathrm{~s}, 6 \mathrm{H}\right.$, free DMSO- $\left.h_{6}\right) ;-1.19\left(\mathrm{~s}, 3 \mathrm{H}, \mathrm{Ni}(\mathrm{II})-\mathrm{CH}_{3}\right) .{ }^{13} \mathrm{C}$ NMR (DMSO- $d_{6}, 100 \mathrm{MHz}$ ): $\delta 169.3$ (C7); 161.8 (C2); 149.0 (C8); 148.9 (C4); 141.8 (C6), 140.7 (C14, 22); 132.3 (C9, 13); 131.1 (C15, 21, $23,29) ; 131.0(\mathrm{C} 10,12) ; 130.3\left(\mathrm{q},{ }^{2} J_{\mathrm{C}-\mathrm{F}}=33 \mathrm{~Hz}, \mathrm{C} 16,19,24\right.$, 27); 127.1 (C11); 123.3 (q, ${ }^{1} J_{\mathrm{C}-\mathrm{F}}=273 \mathrm{~Hz}, \mathrm{C} 17,20,25,28$ ); 121.5 (q, $\left.{ }^{3} J_{\mathrm{C}-\mathrm{F}}=4 \mathrm{~Hz}, \mathrm{C} 18,26\right) ; 120.1$ (C1); 95.0 (C5); 73.7 (C3); 40.4 (free DMSO- $\left.h_{6}\right) ;-8.03\left(\mathrm{Ni}(\mathrm{II})-\mathrm{CH}_{3}\right)$.

Preparation of [(N,O) Ni( $\left.\left.\mathrm{C}_{2} \mathrm{H}_{5}\right)(\mathrm{DMSO})\right]$ (2-DMSO). A Schlenk flask was charged with $56 \mathrm{mg}$ ( $55 \mu \mathrm{mol})$ of 1-DMSO and $4 \mathrm{~mL}$ of DMSO- $d_{6}$, sealed with a rubber septum, and removed from the glovebox. The flask was connected to a Schlenk line, and the reaction mixture was warmed to $55^{\circ} \mathrm{C}$ under argon in an oil bath. Ethylene was bubbled from a cannula into the solution for $45 \mathrm{~min}$ at this temperature and for an additional $10 \mathrm{~min}$ at $25^{\circ} \mathrm{C}$. The reaction solution was transferred with a $1 \mathrm{~mL}$ syringe inside the glovebox into dry NMR tubes that were sealed with rubber septa. Deuterium-labeled $\mathbf{2}_{\mathrm{d}}$-DMSO was prepared analogously from a 10.3 $\mathrm{mM}$ DMSO- $d_{6}$ solution of 1 -DMSO at $50{ }^{\circ} \mathrm{C}$ using ethylene- $d_{4}$.

${ }^{1} \mathrm{H}$ NMR (DMSO- $d_{6}, 25^{\circ} \mathrm{C}, 400 \mathrm{MHz}$ ): $\delta 8.25$ (br s, $2 \mathrm{H}, \mathrm{H} 18$, 26); 8.23 (s, 1H, H7); 8.17 (br s, $4 \mathrm{H}, \mathrm{H} 15,21,23,29$ ); 7.88 (br s, $1 \mathrm{H}, \mathrm{H} 4) ; 7.67\left(\mathrm{~d},{ }^{3} J_{\mathrm{H}-\mathrm{H}}=7.6 \mathrm{~Hz}, 2 \mathrm{H}, \mathrm{H} 10,12\right) ; 7.53\left(\right.$ br t, ${ }^{3} J_{\mathrm{H}-\mathrm{H}}$ $=7.6 \mathrm{~Hz}, 1 \mathrm{H}, \mathrm{H} 11) ; 7.36(\mathrm{br} \mathrm{s}, 1 \mathrm{H}, \mathrm{H} 6) ;-0.07\left(\mathrm{t},{ }^{3} J_{\mathrm{H}-\mathrm{H}}=7.5\right.$ $\left.\mathrm{Hz}, 3 \mathrm{H}, \mathrm{Ni}(\mathrm{II})-\mathrm{CH}_{2} \mathrm{CH}_{3}\right) ;-0.42$ (br q, ${ }^{3} \mathrm{~J}_{\mathrm{H}-\mathrm{H}}=7.5 \mathrm{~Hz}, 2 \mathrm{H}$, $\left.\mathrm{Ni}(\mathrm{II})-\mathrm{CH}_{2} \mathrm{CH}_{3}\right),{ }^{13} \mathrm{C}$ NMR (DMSO- $\left.d_{6}, 100 \mathrm{MHz}\right): \delta 168.9(\mathrm{C} 7)$; 161.7 (C2); 148.9 (C8); 148.5 (C4); 141.5 (C6); 140.8 (C14, 22); 132.5 (C9, 13); $131.0(\mathrm{C} 10,12) ; 130.6(\mathrm{C} 15,21,23,29) ; 130.3$ (q, $\left.{ }^{2} J_{\mathrm{C}-\mathrm{F}}=33 \mathrm{~Hz}, \mathrm{C} 16,19,24,27\right) ; 127.3(\mathrm{C} 11) ; 123.2\left(\mathrm{q},{ }^{1} J_{\mathrm{C}-\mathrm{F}}=\right.$ $273 \mathrm{~Hz}, \mathrm{C} 17,20,25,28) ; 121.4$ (C18, 26); 120.5 (C1); 95.5 (C5); 73.2 (C3); 14.7 ( $\mathrm{Ni}(\mathrm{II})-\mathrm{CH}_{2} \mathrm{CH}_{3}$ ), 5.0 (br, $\mathrm{Ni}(\mathrm{II})-\mathrm{CH}_{2} \mathrm{CH}_{3}$ ).

\section{Preparation of $\left[(\mathrm{N}, \mathrm{O}) \mathrm{Ni}(\mathrm{H})\left(\mathrm{PMe}_{3}\right)\right] \quad\left(3-\mathrm{PMe}_{3}\right)$.} a. Preparation of $\left[(\mathbf{N}, \mathrm{O}) \mathrm{Ni}(\mathrm{Cl})\left(\mathrm{PMe}_{3}\right)\right]$. A Schlenk flask was charged with $141 \mathrm{mg}(0.5 \mathrm{mmol})$ of $\left[\mathrm{NiCl}_{2}\left(\mathrm{PMe}_{3}\right)_{2}\right]$. Toluene (10 $\mathrm{mL})$ and $\mathrm{NEt}_{3}(0.25 \mathrm{~mL}, 1.79 \mathrm{mmol})$ were added under argon to afford a dark-red solution. A solution of $428 \mathrm{mg}(0.49 \mathrm{mmol})$ of the salicylaldimine $[\mathrm{N}, \mathrm{O}] \mathrm{H}$ in $10 \mathrm{~mL}$ of toluene was slowly added via syringe through a rubber septum using a syringe motor at a rate of $\sim 1 \mathrm{~mL} \mathrm{~h}^{-1}$ overnight. The slow addition of the salicylaldimine solution was necessary to avoid the formation of the bischelate complex $\left[(\mathrm{N}, \mathrm{O})_{2} \mathrm{Ni}\right]$. The solvent was removed in vacuo, and the remaining dark-red-brown oily residue was dissolved in 5 $\mathrm{mL}$ of a $(1: 1)$ mixture of pentane and toluene; the resulting suspension was filtered by cannula. After removal of the solvent in vacuo, the remaining dark-red-brown oily residue was treated with cold methanol to yield a red microcrystalline solid, which was collected by filtration under argon. Yield: $356 \mathrm{mg}(0.34 \mathrm{mmol})$, $69 \%$.

${ }^{1} \mathrm{H}$ NMR $\left(\mathrm{CD}_{2} \mathrm{Cl}_{2}, 25^{\circ} \mathrm{C}, 400 \mathrm{MHz}\right): \delta 8.34$ (br s, $4 \mathrm{H}, \mathrm{H} 15,21$, $23,29) ; 8.01$ (br s, $2 \mathrm{H}, \mathrm{H} 18,26) ; 7.91\left(\mathrm{~d},{ }^{4} J_{\mathrm{H}-\mathrm{H}}=2.4 \mathrm{~Hz}, 1 \mathrm{H}\right.$, $\mathrm{H} 4) ; 7.49-7.46(\mathrm{~m}, 3 \mathrm{H}, \mathrm{H} 10,11,12) ; 7.44\left(\mathrm{~d},{ }^{4} J_{\mathrm{H}-\mathrm{P}}=10.3 \mathrm{~Hz}\right.$, $1 \mathrm{H}, \mathrm{H} 7) ; 7.07\left(\mathrm{~d},{ }^{4} J_{\mathrm{H}-\mathrm{H}}=2.4 \mathrm{~Hz}, 1 \mathrm{H}, \mathrm{H} 6\right) ; 1.11\left(\mathrm{~d},{ }^{2} J_{\mathrm{H}-\mathrm{P}}=12.8\right.$ $\left.\mathrm{Hz}, 9 \mathrm{H}, \mathrm{P}\left(\mathrm{CH}_{3}\right)_{3}\right) \cdot{ }^{13} \mathrm{C}$ NMR $\left(\mathrm{CD}_{2} \mathrm{Cl}_{2}, 25^{\circ} \mathrm{C}, 100 \mathrm{MHz}\right): \delta 166.6$ (C7); 161.7 (C2); 151.6 (C4); 148.5 (C8); 142.8 (C14, 22); 141.9 (C6); $134.2(\mathrm{C} 9,13) ; 132.0\left(\mathrm{q},{ }^{2} J_{\mathrm{C}-\mathrm{F}}=33 \mathrm{~Hz}, \mathrm{C} 16,19,24,27\right)$; $131.6\left(\mathrm{~m},{ }^{3} J_{\mathrm{C}-\mathrm{F}}=3 \mathrm{~Hz}, \mathrm{C} 15,21,23,29\right) ; 131.2(\mathrm{C} 10,12) ; 127.7$
(C11); $124.2\left(\mathrm{q},{ }^{1} J_{\mathrm{C}-\mathrm{F}}=273 \mathrm{~Hz}, \mathrm{C} 17,20,25,28\right) ; 122.0\left(\mathrm{~m},{ }^{3} J_{\mathrm{C}-\mathrm{F}}\right.$ $=4 \mathrm{~Hz}, \mathrm{C} 18,26) ; 120.6(\mathrm{C} 1) ; 94.6(\mathrm{C} 5) ; 75.4(\mathrm{C} 3) ; 12.7\left(\mathrm{~d},{ }^{1} J_{\mathrm{C}-\mathrm{P}}\right.$ $\left.=31 \mathrm{~Hz}, \mathrm{P}\left(\mathrm{CH}_{3}\right)_{3}\right) \cdot{ }^{31} \mathrm{P}\left\{{ }^{1} \mathrm{H}\right\} \operatorname{NMR}\left(\mathrm{CD}_{2} \mathrm{Cl}_{2}, 25^{\circ} \mathrm{C}, 162 \mathrm{MHz}\right): \delta$ $-16(\mathrm{~s})$.

b. Preparation of 3-PMe . A Schlenk flask was charged with $150 \mathrm{mg}(0.14 \mathrm{mmol})$ of $\left[(\mathrm{N}, \mathrm{O}) \mathrm{Ni}(\mathrm{Cl})\left(\mathrm{PMe}_{3}\right)\right]$ and $76 \mathrm{mg}(0.59$ $\mathrm{mmol})$ of $\mathrm{NaHB}(\mathrm{OMe})_{3}$ in a glovebox. After the flask was removed from the glovebox, it was cooled to $-60{ }^{\circ} \mathrm{C}$ in a cold bath, and a mixture of $10 \mathrm{~mL}$ of diethyl ether and $2 \mathrm{~mL}$ of THF was added under argon to afford a dark-brown suspension. While the solution was stirred, the temperature was slowly increased to $-10^{\circ} \mathrm{C}$. After an additional $2 \mathrm{~h}$ of stirring at $-10^{\circ} \mathrm{C}$, the solvent mixture was completely removed under high vacuum. The resulting brown residue was dissolved in $10 \mathrm{~mL}$ of precooled diethyl ether at -60 ${ }^{\circ} \mathrm{C}$ to afford an orange-brown solution containing a white precipitate. The suspension was stirred for $15 \mathrm{~min}$ at $-60^{\circ} \mathrm{C}$ and then quickly filtered through a plug of diatomaceous earth, which was extracted with small portions of cold diethyl ether. After the removal of the solvent under high vacuum at $-10^{\circ} \mathrm{C}$, an orange solid was obtained, which was recovered in a glovebox. Yield $47 \mathrm{mg}(0.05$ $\mathrm{mmol}$ ), 33\%. Depending on to which extent the THF solvent was removed before the filtration step, the product may contain up to $30 \%$ of inorganic material, sodium chloride, and residual THF. However, the addition of THF is necessary to achive any conversion into the $\mathrm{Ni}$ (II)-hydride complex.

${ }^{1} \mathrm{H}$ NMR (THF- $d_{8},-60^{\circ} \mathrm{C}, 400 \mathrm{MHz}$ ): $\delta 8.50$ (br s, $4 \mathrm{H}, \mathrm{H} 15$, $21,23,29) ; 8.10$ (br s, $2 \mathrm{H}, \mathrm{H} 18,26) ; 8.01\left(\mathrm{~d},{ }^{4} J_{\mathrm{H}-\mathrm{P}}=8.7 \mathrm{~Hz}, 1 \mathrm{H}\right.$, $\mathrm{H} 7) ; 7.94\left(\mathrm{~d},{ }^{4} J_{\mathrm{H}-\mathrm{H}}=2.3 \mathrm{~Hz}, 1 \mathrm{H}, \mathrm{H} 4\right) ; 7.61\left(\mathrm{~d},{ }^{3} J_{\mathrm{H}-\mathrm{H}}=7.0 \mathrm{~Hz}\right.$, $2 \mathrm{H}, \mathrm{H} 10,12) ; 7.54$ and $7.52\left(\mathrm{dd},{ }^{3} J_{\mathrm{H}-\mathrm{H}}=7.0 \mathrm{~Hz}, 1 \mathrm{H}, \mathrm{H} 11\right) ; 7.29$ $\left(\mathrm{d},{ }^{4} J_{\mathrm{H}-\mathrm{H}}=2.3 \mathrm{~Hz}, 1 \mathrm{H}, \mathrm{H} 6\right) ; 1.26\left(\mathrm{~d},{ }^{2} J_{\mathrm{H}-\mathrm{P}}=10.5 \mathrm{~Hz}, 9 \mathrm{H}\right.$, $\left.\mathrm{P}\left(\mathrm{CH}_{3}\right)_{3}\right) ;-26.84\left(\mathrm{~d},{ }^{2} J_{\mathrm{H}-\mathrm{P}}=142.8 \mathrm{~Hz}, 1 \mathrm{H}, \mathrm{Ni}(\mathrm{II})-H\right) .{ }^{13} \mathrm{C} \mathrm{NMR}$ (THF- $\left.d_{8},-60^{\circ} \mathrm{C}, 100 \mathrm{MHz}\right): \delta 166.9(\mathrm{C} 7) ; 163.9(\mathrm{C} 2) ; 154.8(\mathrm{C} 8)$; 150.1 (C4); 143.4 (C6); 142.7 (C14, 22); 132.9 (C9, 13); 132.1 $(\mathrm{C} 10,12) ; 131.9(\mathrm{~m}, \mathrm{C} 15,21,23,29) ; 131.9\left(\mathrm{q},{ }^{2} J_{\mathrm{C}-\mathrm{F}}=33 \mathrm{~Hz}\right.$, $\mathrm{C} 16,19,24,27) ; 127.5(\mathrm{C} 11) ; 124.8\left(\mathrm{q},{ }^{1} J_{\mathrm{C}-\mathrm{F}}=274 \mathrm{~Hz}, \mathrm{C} 17,20\right.$, 25, 28); $122.2\left(\mathrm{~m},{ }^{3} J_{\mathrm{C}-\mathrm{F}}=3 \mathrm{~Hz}, \mathrm{C} 18,26\right) ; 121.1$ (C1); 98.4 (C5); $73.6(\mathrm{C} 3) ; 15.7\left(\mathrm{~d},{ }^{1} J_{\mathrm{C}-\mathrm{P}}=31 \mathrm{~Hz}, \mathrm{P}\left(\mathrm{CH}_{3}\right)_{3}\right) .{ }^{31} \mathrm{P}$ NMR $\left(\mathrm{THF}-d_{8}\right.$, $-60{ }^{\circ} \mathrm{C}, 162 \mathrm{MHz}$ ): $\delta-8.1$ (doublet of multiplets, ${ }^{2} J_{\mathrm{P}-\mathrm{NiH}}=143$ $\mathrm{Hz},{ }^{2} \mathrm{~J}_{\mathrm{P}-\mathrm{H}}=10.5 \mathrm{~Hz}$ ).

Direct Observation of Catalytic Chain Growth by Variable-Temperature ${ }^{1} \mathrm{H}$ NMR Spectroscopy. In a typical experiment, a $26 \mathrm{mM}$ DMSO- $d_{6}$ solution of 1 -DMSO was prepared in an NMR tube that was sealed with a rubber septum. The tubes were kept at room temperature outside the spectrometer, and ${ }^{1} \mathrm{H}$ NMR spectra were taken at $55^{\circ} \mathrm{C}$. Water $\left(16 \mu \mathrm{L}, \mathrm{D}_{2} \mathrm{O}=60\right.$ equiv) and ethylene $(3-4 \mathrm{~mL})$ were added via gas-tight syringes. Relative concentrations of free ethylene, propene, butenes, and 2-DMSO were determined from integration of the respective resonances and normalization to $\left[\mathrm{Ni}(\mathrm{II})-\mathrm{CH}_{3}\right]=1$ at $t=0$. The resonance of free DMSO- $h_{6}$ was used as an internal standard to calculate molar concentrations. The gradual disappearance of the $\mathrm{Ni}$ (II) $-\mathrm{CH}_{3}$ resonance of 1-DMSO was monitored at $55^{\circ} \mathrm{C}$ after ethylene addition. A plot of $\ln \left([1-\mathrm{DMSO}]_{t} /[1-\mathrm{DMSO}]_{t=0}\right)$ versus time was linear in the presence of excess ethylene. Linear regression provided pseudo-first-order rate constants $k_{\text {ins, Me }}$.

General Procedure for the Kinetic Analysis of Ethane Formation from 1-DMSO. Solutions of 1-DMSO in DMSO- $d_{6}$ $(15-24 \mathrm{mM})$ were prepared in a glovebox. The tube was sealed with a rubber septum and removed from the glovebox. The sample was introduced to the prewarmed NMR probe, and the decrease of the $\mathrm{Ni}(\mathrm{II})-\mathrm{CH}_{3}$ resonance with time was followed by variabletemperature ${ }^{1} \mathrm{H}$ NMR spectroscopy. Integral values were normalized to the value at $t=0$ and converted into concentrations by multiplication with the starting concentration of 1-DMSO. The resonance of free DMSO- $h_{6}$ was used as the internal standard. Second-order rate constants $k_{\mathrm{Me}-\mathrm{Me}}(T)$ were calculated from linear regressions of plots of $1 /[1-\mathrm{DMSO}]_{t}-1 /[1-\mathrm{DMSO}]_{t=0}$ versus time (Figure S12 in the Supporting Information). Linear regression of an Eyring plot of the temperature dependence of $k_{\mathrm{Me}-\mathrm{Me}}(T)$ (i.e., a 
plot of $\ln \left[k_{\mathrm{Me}-\mathrm{Me}}(T) / T\right]$ vs $\left.1 / T\right)$ provided the activation parameters $\Delta H^{+}$and $\Delta S^{+}$.

Methane Formation from 1-DMSO and 3-PMe $\mathrm{P}_{3}$ in $\mathrm{CD}_{2} \mathrm{Cl}_{2}$. NMR tubes were charged with $5 \mathrm{mg}(4.9 \mu \mathrm{mol})$ of 1-DMSO and $7 \mathrm{mg}(6.9 \mu \mathrm{mol})$ of $3-\mathrm{PMe}_{3}(1.4$ equiv of $\mathrm{Ni}(\mathrm{II})-\mathrm{H}$ per $\mathrm{Ni}(\mathrm{II})-\mathrm{CH}_{3}$ ), sealed with rubber septa (fixed with Nesco Film), and cooled to $-30{ }^{\circ} \mathrm{C}$ in a cold bath outside the glovebox. $\mathrm{CD}_{2} \mathrm{Cl}_{2}$ $(600 \mu \mathrm{L}$ ) was slowly added via syringe, and the tubes were shaken thoroughly to dissolve the solids, giving clear orange solutions. The samples were transferred from the cold bath directly to the prewarmed NMR probe, and ${ }^{1} \mathrm{H}$ NMR spectra were acquired at predefined time intervals. For data analysis, integral values of the $\mathrm{Ni}(\mathrm{II})-\mathrm{H}, \mathrm{Ni}(\mathrm{II})-\mathrm{CH}_{3}$, and $\mathrm{Ni}(\mathrm{II})-D M S O$ resonances (the averaged sum of cis and trans isomers in each case) were determined and normalized to $\mathrm{Ni}(\mathrm{II})-H=1$ at $t=0$. The concentrations of the reactants were calculated from the intial concentration of 1-DMSO. Second-order rate constants $k_{\mathrm{H}-\mathrm{Me}}(T)$ were determined from linear regression of plots of $\left(\left[3-\mathrm{PMe}_{3}\right]_{t=0}-[1-\mathrm{DMSO}]_{t}\right.$ $=0)^{-1} \ln \left(\left[3-\mathrm{PMe}_{3}\right]_{t}[1-\mathrm{DMSO}]_{t=0} /\left\{\left[3-\mathrm{PMe}_{3}\right]_{t}=0[1-\mathrm{DMSO}]_{t}\right\}\right)$ versus time (Figure S13 in the Supporting Information). Linear regression of an Eyring plot of the temperature dependence of
$k_{\mathrm{H}-\mathrm{Me}}(T)$ (i.e., a plot of $\ln \left[k_{\mathrm{H}-\mathrm{Me}}(T) / T\right]$ vs $1 / T$ ) provided the activation parameters $\Delta H^{\ddagger}$ and $\Delta S^{\ddagger}$.

Acknowledgment. Financial support by the DFG (Me1388/32) is gratefully acknowledged. We thank Prof. Heiko M. Möller for discussions of NMR spectroscopy and Anke Friemel and Ulrich Haunz for technical support and Lars Bolk for GPC and DSC measurements. S.M. is indebted to the Fonds der Chemischen Industrie and to the Hermann-Schnell Foundation.

Supporting Information Available: Additional NMR spectroscopic data on the characterization and dynamics of 1-DMSO in $\mathrm{CD}_{2} \mathrm{Cl}_{2}$ and methanol- $d_{4}$ solution, the characterization, dynamics, and deactivation pathways of 2-DMSO in DMSO$d_{6}$ solution, and comprehensive kinetic data obtained from NMR spectroscopic studies on the deactivation processes from 1-DMSO. This material is available free of charge via the Internet at http://pubs.acs.org. 